ECONOMIC GROWTH CENTER

YALE UNIVERSITY

P.O. Box 208269

New Haven, CT 06520-8269

http://www.econ.yale.edu/ egcenter/

CENTER DISCUSSION PAPER NO. 901

\title{
Demographic Determinants of Savings: Estimating and Interpreting the Aggregate Association in Asia
}

\author{
T. Paul Schultz \\ Yale University
}

December 2004

Notes: Center Discussion Papers are preliminary materials circulated to stimulate discussions and critical comments.

Prepared for the $10^{\text {th }}$ Anniversary Conference for the China Center for Economic Research at Peking University, Beijing, September 16-17, 2004. Jeremy Magruder, Xin Yu, and Paul McGuire provided valuable assistance in collecting and processing the data analyzed in Section 5, the Rockefeller Foundation supported related training and research, and the MacArthur Foundation's network discussion clarified some of the issues. I appreciate the comments of Athar Hussain and conference participants, and my colleagues Michael Boozer and Gustav Ranis. The author is responsible for the remaining shortcomings <paul.schultz@yale.edu>.

This paper can be downloaded without charge from the Social Science Research Network electronic library at http://ssrn.com/abstract=639187

An index to papers in the Economic Growth Center Discussion Paper Series is located at: http://www.econ.yale.edu/ egcenter/research.htm 


\title{
Demographic Determinants of Savings: Estimating and Interpreting the Aggregate Association in Asia
}

\author{
T. Paul Schultz
}

\begin{abstract}
Life cycle savings is proposed as one explanation for much of the increase in savings and economic growth in Asia. The association between the age composition of a nation's population and its savings rate, observed within 16 Asian countries from 1952 to 1992, is reestimated here to be less than a quarter the size reported in a seminal study, which assumed lagged savings is exogenous. Specification tests as well as common sense imply, moreover, that lagged savings is likely to be endogenous, and when estimated accordingly there remains no significant dependence of savings on the age composition, measured in several ways. Research should consider lifetime savings as a substitute for children, and model the causes for the decline in fertility which changes the age compositions and could thereby account for savings and growth in Asia.
\end{abstract}

Key words: Life cycle savings, Aging, Asian growth, Demographic transition

JEL codes: D91, J11, O11, O53 


\section{Introduction}

The age composition of a country's population may be associated with its saving rate, and may therefore have consequences for its economic growth. One explanation for such an association is that the savings rate tends to be relatively high for a birth cohort when it experiences its peak earnings, and relatively low when a cohort anticipates relatively low earnings, such as during retirement. Variations in the age composition of a population may then determine variations in national savings rates, over time and across countries, holding other things equal. This life cycle savings hypothesis is intuitively appealing, and economists and demographers have explored the theoretical and empirical implications of the hypothesis following Modigliani and Brumberg (1954). This paper reexamines this empirical association within Asian countries, where the changing age compositions has been attributed a central role in the recent increase in savings and economic growth (e.g. Higgins and Williamson, 1996, 1997). The estimated magnitude of this dynamic aggregate relationship appears to be smaller than reported, and sensitive to the choice of econometric methods used to describe it. Moreover, studies of savings behavior at the household level do not find sufficient life cycle variations in savings to account for these purported aggregate relationships. Are there alternative explanations for the trends in savings? The substitution of savings for children is one possible explanation for these empirical regularities, which could be explained within a household lifetime demand framework.

\section{Models of Savings Associated with the Age Composition}

Modigliani and Brumburg (1954) (hereafter MB) assume in their life cycle (LC) model that individuals maximize lifetime utility by allocating lifetime discounted income to consumption in various periods of the life cycle by using capital markets, to equalize the discounted marginal utility of consumption in each period, assuming diminishing marginal utility of consumption in each period. Friedman's (1957) permanent income hypothesis shares many of the same features, emphasizing also smoothing of consumption from "transitory variation" in realized income. Browning and Lusardi (1996) characterize both approaches within a common certainty equivalence model, because they both rely on an inter-temporally additive utility function and a capital market, from which predictions are derived for short-run and long-run consumption-smoothing behavior. Browning and Lusardi note, however, the popularity of this model of consumption behavior should not blind us to the many empirical studies which fail to confirm the importance of the life cycle motivation for consumption smoothing behavior in high- and low-income countries.

There are no children in the LC model; the individual enters the model as an adult at the "beginning of the earnings span" and "receives utility only from present and prospective consumption and from assets" (MB, p.394), and the individual as a head of a household is responsible for saving and consumption until his or her 
death, the timing of which involves no uncertainty. MB explicitly assume that "the typical household does not inherit assets to any significant extent and does not plan on leaving assets to heirs", and they thereby set aside intergenerational transfers or bequests, avoiding explicit recognition of children, marriage, household formation, or labor supply choices. The adult individual earner eventually retires and over her or his life cycle has zero present discounted savings. With no population or income growth in a steady state, aggregate savings is also zero, but savings will tend to rise if the population increases and/or income per capita grows.

Demographers modified this LC scheme by introducing an early life-cycle stage of dependency which could depress public as well as private savings. In other words, childhood as well as retirement is added to the life cycle. The demographic transition in a country such as India - when mortality and fertility rates decline affects promptly the fraction of children in the population, but only impacts substantially the fraction of elderly after a time, because much of the early decline in mortality occurs as infants and children survive in greater numbers (Coale and Hoover, 1958). According to recent restatements of this framework called the "demographic dividend", a rapid demographic transition facilitates a large increase in the rate of national savings after a decade or two, followed by a gradual peaking in savings and then an expected decline in the rate of saving after four or more decades, as an increasing share of the population retires (e.g. Higgins and Williamson, 1996; Bloom and Williamson, 1998; Mason, 2001; Birdsall et al, 2001).

Economists have also extended the LC model to link micro behavior to aggregate growth dynamics. Tobin (1967) portrayed more realistically than MB how the ratio of savings to income and the ratio of wealth to income would evolve. His goal was to assess whether the life cycle savings hypothesis could account for the observed wealth and savings outcomes in a setting such as the United States in the 1960s. Tobin allowed for a "positive interest rate, probabilistic life span, empirically calibrated income profiles for men and women, and added childhood as well as old age (i.e. two periods of dependency with dissaving), with a changing family structure" over the life cycle, by allowing the age and sex composition of a representative household in a birth cohort to change as the household's head ages. Tobin then describes "golden-age" growth paths for savings and wealth ratios determined by specified values for the rate of interest, rates of growth of population, and rates of growth of per capita income. But this more detailed empirical calibration still assumes fertility and family formation are not coordinated decisions but are determined exogenously from outside of the savings model. Coale and Hoover (1958) also demographically assume mortality and fertility occur independently of life cycle savings behavior. The problem with all of these frameworks is that they view fertility as fixed from outside of the model and thus not a resource-constrained lifetime choice. If fertility is allowed to be jointly determined with savings and female labor supply, the implications of the life cycle model for the pattern of income, consumption and savings becomes more complex. 
The relationship between children and savings is not resolved in theoretical terms and is relatively unexplored in empirical work at either the aggregate or family level. Children are widely thought to function as an intertemporal investment, or a mechanism for transferring resources over the life cycle of parents from a period of relatively high adult productivity to a period of relatively low productivity in old age. In this case, it is reasonable to expect children to substitute, to some degree, for monetized savings that accomplish the same ends for parents. When parents decide to reduce their lifetime fertility, the scarcity or marginal value to them of other forms of savings and wealth is likely to increase, other things being equal. Samuelson (1958) concluded parents are motivated to have children in part by the expectation that their children will help support and care for them in old age. This essential function of the family has given rise to an extensive literature of overlapping generations models of savings, intergenerational transfers, and growth. An "exogenous" reduction in fertility would motivate parents to substitute more of their resources into savings and wealth accumulation in other forms for their old age support. Unless additional assumptions are made, however, it is unclear how an "endogenous" declines in fertility would "impact" parent savings and accumulation of a portfolio of wealth, without also modeling the determination of fertility.

If a primary reason for adults to have children is to assure for their consumption and care in retirement and during periods of disability -- a form of social insurance as well as savings -- smaller family sizes might be expected to boost parent savings rates out of lifetime income and increase the demands of parents for public and private pensions. When parents decide to reduce their fertility, their savings rates should then increase, other things equal. But the changed environment which led them to restrict their fertility may have increased or decreased their lifetime wealth, and thereby affected how much they want to consume and save, or the relative returns to saving in the form of human capital, land and other physical assets. From the children's perspective, their motivation to save to provide for the consumption and care of their parents when the parents are old will also be intensified by the parent's decision to reduce their fertility, leaving any burden of parent support to a smaller number of offspring. ${ }^{1}$

Becker (1981) hypothesized that the quantity of children and the quality of children, proxied by the human capital invested in each child, are viewed by parents as substitute objectives. If quantity and quality of children are indeed substitutes, this would help to account for a negative covariation between fertility and the savings of parents allocated to investment in human capital per child (Schultz, 1981, 2002). But does the

\footnotetext{
${ }^{1}$ Children who have benefited from their parents' growing investment in their human capital may also be more likely to honor the implicit intergenerational annuity contract for supporting elderly parent, unless pensions and medical care for the elderly are provided by the state (Kotlikoff, 1988).
} 
substitution of quality for quantity of children fully offset the decline in number of children during the demographic transition and lead parents to increase their lifetime savings as the demographic transition proceeds? Evidence is scarce. If fertility declines by more than half, as we have seen widely in the world, parents would have to more than double their investments per child in human capital to achieve an absolute rise in this form of savings per parent. Jorgenson (1995) treats parent investments in children as "savings" in his national accounts, and by his reckoning there has been an increase in the household savings rate for investment in children in the United States in the $20^{\text {th }}$ century. But such comprehensive measures of household savings that includes household production of child human capital are not a standard convention of national accounts, and thus they are not available for study in other countries.

The LC model assumes that children do not influence wealth accumulation. This appears implausible to me, even if the sign and magnitude of the cross effect depends on unknown underlying parameters and controversial modeling assumptions (Browning, 1992). There is evidence, however, that unanticipated variation in fertility affects female labor supply, and thus market income over the life cycle (Rosenzweig and Wolpin, 1980b), and it affects investment in human capital per child and probably household total savings (Rosenzweig and Wolpin, 1980a; Rosenzweig and Schultz, 1987). Consequently, I expect that in the last 40 years as fertility has fallen rapidly in East, Southeast, and then South Asia (Figure 1), household savings rates increased among later-born generations of parents as their lifetime fertility declined. This occurred more gradually when fertility declined in the $19^{\text {th }}$ Century United States (Lewis, 1983).

There are thus two basic models that imply different mechanisms linking the decline in fertility to the rise in aggregate savings rates. The first LC model assumes that the age profile of savings rates motivated by retirement operates uniformly across birth cohorts in a society, holding constant lifetime income. If the proportion of the population in the dependent ages decreases -- younger than say 20 and older than 60 -aggregate savings rates will tend to increase. Thus, during the demographic transition as fertility declines, the decrease in the proportion of the population in the youth-dependent category outweighs the small increase in the proportion of the population in the elderly-dependent category, and aggregate savings rates will tend to increase for at least a decade or two, other things being equal. About forty years after a steep decline in fertility, the dependency rate starts to increase as the growth in the elderly proportion of the population outweighs any further decline in the proportion of dependent youth. The pace of the transition and precise path of birth and age-specific death rates will determine how soon and how severely the country encounters the eventual savings shortfall associated with an aging population (See Figures 2). Taxes and transfers may mitigate the economic and social problems associated with an aging population - by providing pensions and medical care for the elderly, by encouraging those qualifying for transfers and pensions to continue to work, 
and by regulating the level and composition of immigration to increase the share of workers in the population (e.g. Heller, 2003).

The second model considers the household as demanding (HD) children and other consumption goods over a lifetime, and couples modify their choices because of changes in prices, wages, returns on wealth, and technological opportunities. If parents view their demand for precautionary and retirement wealth as a substitute for children, cohorts who are born later and have begun to reduce their fertility for a variety of reasons will also increase their savings. Investment by households in the health and schooling of their children may also increase, which may spur growth and improve the well being of the population.

\section{How do the Life Cycle and Household Demand Models of Savings Differ?}

The aggregate trends in age composition and savings accounted for by the LC model are also consistent with the HD model of lifetime fertility and wealth accumulation. I know of no empirical studies that assess which framework better explains the historical record (Heller, 2003). In the LC model the key concept is the profile of savings by age, motivated by retirement, whereas the HD model extends the framework to account for a variety of household lifetime behaviors, and thus allows more incentives for households to have children and to save in the various forms of assets.

In a general equilibrium framework, an exogenous increase in the aggregate supply of savings should diminish the returns to savings and thus curb the supply of savings. If the economy is open to world capital markets, the effect of the domestic savings supply on returns would be moderated. As countries experience major changes in their age composition due to the timing and pace of their demographic transition, international capital flows may respond accordingly (Taylor and Williamson, 1994). Higgins and Williamson (1996, 1997) (hereafter HW) estimate jointly the equations for aggregate savings rates and aggregate investment rates, presumably allowing omitted variables to affect errors in both the savings and investment equations. In their linear specification, any difference between the effect of the age composition on aggregate savings and on investments is equal to the effect of the age composition on the current account surplus (or deficit if negative) in an internationally open economy. HW expect the age composition of the population to affect aggregate domestic investment opportunities, leading investment rates to peak when a population is concentrated in younger adult ages, whereas savings rates peak for somewhat older workers who are at their peak earnings. An economy open to international capital flows will therefore be inclined to borrow from abroad when it has a youthful age composition which creates a domestic shortage of savings relative to investment opportunities. Conversely, a country will tend to export its surplus savings when it has a disproportionate share of its population in the prime working ages. For example, Europe invested much of its savings in the New World 
and Russia during the period 1870-1910, and some view this as an international intergenerational transfer, and explain it in terms of differences in age structures as they do the swings in current account balances from negative to positive from 1960-2000 in Japan, Singapore, Taiwan, and Korea (Taylor and Williamson, 1994, HW, 1996: Table 4). ${ }^{2}$

One possible way to distinguish between the LC and HD models is to see whether different observable exogenous causes for the decline in fertility exert different "cross-effects" on savings, as might be expected within the HD model. Different causes for the same fertility changes would have the same effect on the age composition and would be indistinguishable in the LC model of savings. ${ }^{3}$ The rise in the opportunity cost of children due to the rise in women's wage opportunities outside of the family may have reduced the demand for children and contributed to the secular decline in birth rates (Mincer, 1963; Schultz, 1981, 2002). The increase in the returns to child human capital may also have led parents to substitute child quality for the number of children parents demand (Becker, 1981). The new technological options for birth control (i.e. the oral steroid pill and the IUD) spread through the world after the 1960s and decreased the cost of birth control, encouraging fertility to decline.

Population policies which subsidize a voluntary fertility decline are expected to have a smaller effect on savings than an equally effective fertility-rationing scheme, such as the birth quota (i.e. one-child family) adopted in China after 1970. Although both voluntary reproductive choices and birth quotas might achieve the same magnitude of decline in fertility, in perhaps Hong Kong, Taiwan and China, the impact on savings from China's policy of birth quotas would presumably be larger, if savings and children are substitutes. Tobin and Houthtakker (1950-51) demonstrate that rationing causes a larger cross-commodity shift in household demands toward substitutes in the HD model, but this would not be expected in the LC model that implicitly assumes children and savings are independent choices. Even though the birth quota may have stimulated savings, it also must have sacrificed the welfare of the poor rural population, who had their reproductive choices restricted without compensation (Schultz, 2004). Johnson (1999) has argued cogently that there is little empirical or theoretical evidence for the belief that reducing Chinese fertility and slowing population growth has fostered Chinese development, but it remains unclear whether it could have boosted personal savings.

\footnotetext{
${ }^{2}$ Higgins (1998) illustrates how the jointly estimated savings and investment equations are modified when total savings and investment are restricted to be equal (i.e. in a closed economy) and when they are permitted to differ (i.e. in an open economy). The age composition effects on savings are estimated to be weaker in the open than in the closed economy, as expected from the general equilibrium model.

3 Another way to think of this heterogeneity is in terms of local area treatment estimators (LATE) in which the response of savings to age might be a random coefficient for the population as a whole, and the actual savings response
} 


\section{Macro and Micro Empirical Evidence of Savings and Aging}

The empirical relationship between age and savings has been studied using a variety of approaches with macro data for countries and micro data for households. This section reviews the findings of some of these studies. Leff (1969) found across 74 countries in 1964 that the log of gross savings rates is inversely related to the fraction of the population under age 15, and the fraction over age 64, while controlling for log GDP per capita, and log growth of GDP per capita in the previous five years. However, Leff's findings were criticized because of his handling of the data, specification of his variables, sample composition, and estimation methods. Kelley and Schmidt (1996) preserved the simplicity of his approach and corrected many of his problems in their later analysis of data for 89 countries for three decades of the 1960s, 1970s, and 1980s. They find savings rates are higher in countries with higher GDP per capita (not a conclusion of the LC model), with higher growth in GDP per capita (implied by LC stable-state and dynamics), and not significantly related to the fraction of youth and elderly in 1960s or the 1970s. However, by the 1980s the fraction of youth and elderly were negatively related to the savings rate, as predicted by the LC model. Estimates of this "Leff" model for the pooled three cross sections revealed no relation between savings and the relative size of the two dependent age groups in the population, whereas when changes over time within country were estimated by including both country fixedeffects and decade-shifters, the youth fraction is unexpectedly associated with higher savings. ${ }^{4}$

MB (1954) state that within their framework the effect of age composition on saving is nonlinear and varies with income growth. After adding to the LC model the childhood dependency phase in the life cycle, Tobin (1967) simulated the path of aggregate savings, to show its sensitivity to per capita income growth and the consumption weights assigned to children. Fry and Mason (1982) propose an aggregate LC savings model which includes an interaction effect between the fraction of dependent youth and growth in income, which is expected to depress savings (Mason, 1987). Kelley and Schmidt (1996) incorporate this feature in their second set of regressions by including growth in income, the youth dependency share, and the interaction of the youth share and growth variables. ${ }^{5}$ The estimated savings effect of the interaction of income growth and youth

would differ according to the instruments which modified fertility in the past (Angrist, Imbens and Rubins, 1996).

${ }^{4}$ Kelley and Schmidt (1996; Table 1) specify their youth variable as the ratio of persons age 0 to 14 to the labor force activity age 15-65, and the elderly as the ratio of those over 65 to the labor force age. They then restrict their sample to only less developed countries (LDCs, $n=65$ ), in which case neither the youth nor elderly population fractions is significantly related to savings in any of the three decadal cross sections.

${ }^{5}$ The original MB life cycle model did not imply that the fraction of income saved would increase with income per capita as Leff and Modigliani specified in their early empirical work across countries. It is not clear, however, why Kelley and Schmidt (1996) exclude the elderly dependent population fraction from their "Mason" model. A negative correlation between the fraction of youth and elderly is likely to influence other estimated coefficients when the elderly fraction is dropped. Leff (1969; p. 890) noted a weakness of his results was the high collinearity between the income and dependency population age fractions, leading to unstable and unreliable estimates in his cross-country regressions. Kelley and Schmidt also transform the dependent variable for the savings rate to $(1 /\{1-\mathrm{S} / \mathrm{Y}\})$ and thereby avoid taking logs of near zero or negative saving rates, one flaw in Leff's original specification. For the same reason Schultz (1999) analyzes the log of consumption rates out of current income at the household level in his investigations. 
dependency is negative in the cross section regression for the 1960s, 1970s, and 1980s, and in the pooled and country fixed-effect model specifications (Kelley and Schmidt, 1996, Table 2). When they restrict their sample to low income countries (i.e. 56 out of 89 countries), the youth dependency fraction interacted with income growth is negatively associated with savings only in the 1980s, and in the pooled and fixed effect specifications. Based on this "Mason" model and excluding the effect of the elderly, Kelley and Schmidt conclude demographic factors (now only the youth) account for a major portion of changes in savings across countries and over time, and appear to be robust across various country samples, model specifications, and estimation methods. ${ }^{6}$

Microeconometric tests of the predictive power of the life cycle framework in accounting for savings behavior at the household level had even less success. The correlation of consumption and income is high in household surveys across groups of households whose head has the same age, and even within a birth cohort followed statistically over time in repeated independently drawn cross sectional surveys. In other words, average consumption does not deviate much from average income across ages. This micro empirical regularity is difficult to account for, because the life cycle savings framework anticipated consumption is displaced from periods of expected high income to those with expected low income (Lee and Lapkoff, 1988; Carroll and Summers, 1991; Paxson, 1996; Deaton, 1997; Schultz, 1998). As a consequence, other motivations for savings are often advanced to explain household savings data, such as precautionary or buffer-stock savings to insure against risks and the uncertainty of the individual's lifetime, and the desire of the elderly to leave a bequest to heirs (Browning and Lusardi, 1996; Deaton, 1997).

A possible explanation for the small magnitude of micro-empirical estimates of life cycle savings is because age is measured by the age of the head of household, and individuals who are not heads (or spouse of heads) are not the focus of analyses of life cycle savings behavior. If the young and old who are most likely to be dissaving are not observed to be household heads because they live in their parents' or children's household, respectively, the convexity of the savings rate profile with respect to age may be underestimated. Although the likelihood of being a head of household may be close to one from age 30 to 50, it will be far below one among younger and older persons on whom any test of the life cycle savings hypothesis critically depends (Schultz, 1999). ${ }^{7}$

${ }^{6}$ In a cross-country study of 36 primarily high-income countries, Modigliani compared estimates of the LC and Keynesian models of savings. Because the countries did not correspond with the steady-state equilibria described by his model, he represented the effect of population growth on savings by the population shares of youth and elderly, which were associated with lower savings rates.

${ }^{7}$ For example, in 1976 in Taiwan only one in four individuals age 20-24 were heads of their own household or spouse of the head, and about three out of ten of those age 65 to 69 were heads. With the increase in income, post-secondary education, and 
If wealth income of an individual increases his or her likelihood of being a household head, but does not otherwise affect the savings rate, the savings equation can then be estimated, correcting for the unrepresentative character of the sample of household heads, and the sample selection model is identified by this exclusion restriction. In Taiwan in 1967 and 1995 the young who are heads of their own households have significantly more wealth income than would be expected of the average young person. Among the elderly over age 59, those who are heads of their household also have greater than average wealth income for their age, and expected to save a more substantial share of their income than those who are younger. In other words, correcting for the sample selection bias of being a head of household across age groups suggests that the implicit savings behavior of the young is lower than observed which would be consistent with the life cycle hypothesis, possibly even borrowing from their parents or credit institutions. But the sample selection correction does not modify much the implicit savings behavior of the elderly, who continue to save a positive fraction of their income, which seems to contradict the simple LC hypothesis (Browning and Lusardi, 1996). Indirect standardization for the age composition of persons who are not the heads of their own household leads to a similar conclusion (Deaton and Paxson, 1997). In conclusion, the micro household studies of savings have not found evidence consistent with the large negative aggregate association reported between the share of youth and elderly in a nation and the national savings rate (Mason, 2001).

\section{Data Differences between Savings in Household Surveys and National Income Accounts}

Savings measured in household surveys and as derived in national accounts might differ, possibly explaining why micro econometric evidence on savings is not consistent with macro evidence on life cycle savings. First, savings in national accounts generally includes savings of private enterprises which may not be reported in household surveys as savings. The surplus or deficit on government accounts is also included in national account savings, but is not included in household savings. These non- household sources of output and savings might grow (or decline) as a fraction of income/output with development, as the share of employment in the formal and government sectors increases and the share of employment in family enterprises decreases. But it is unclear whether these additions to private household survey savings tend to raise the level of national account savings compared with survey savings or change the trend with development.

Second, household surveys often underestimate personal income, compared with estimates derived 
from national accounts. One argument for relying on the sum of total household expenditures and imputed services from consumer durables as a more reliable survey-based measure of household welfare than survey reports of income is that expenditures are reported more completely because the typical survey devotes more questions to types of expenditure than to sources of income (Bhalla, 2001; Deaton, 2003). Because household survey estimates of income generally understate national accounts estimates of income, the surveys also tend to imply lower average savings rates than those derived from national accounts.

Expenditures on consumer durables and housing are underestimated in household surveys by a larger proportion than other consumption items, understating this form of savings which is especially important among young families (Bhalla. 2001). Such a systematic pattern of under-enumeration of savings in the form of consumer durables in surveys might tend to understate the life cycle swing in savings as hypothesized by life cycle savings model.

Survey measures of savings may not capture the same share of total savings for persons at different ages, and estimates of the relationship of savings with age in surveys may consequently be misleading. As noted above, the age of the household head summarizes the household's stage in the life cycle, but thereby ignores individuals who are not the household head (or spouses of the head if of similar age). But these individuals who do not head their own household may nonetheless influence the household's savings rate. For example, individuals who are young or elderly are less likely to be heads of their own household, except when they are unusually productive, or receive unusual transfers from their intergenerational family to support living separately (Schultz, 1999).

In conclusion, efforts to analyze savings in household surveys by the age of household head should incorporate information on household composition to try and correct the bias arising from sample selection, and the relative under-enumeration of savings embodied in consumer durables. The omission of some non-household business savings and government savings (or dissavings) could lead to a different level of savings derived from household surveys than national accounts. However, research has not shown how this would distort the life cycle pattern of savings in household surveys.

\section{Aggregate Evidence in Asia of the Association between Age Composition and Savings}

Higgins and Williamson $(\mathrm{HW})(1996,1997)$ estimate the relationship between a country's age composition and savings rate. Their study is cited as providing an explanation for the "East Asian Miracle", and 
suggests policies which facilitated the demographic transition by lowering fertility rates were responsible for opening a "window of economic opportunity" and yielding a "demographic dividend" driven by the changing age composition of the population, which is causally related to increasing savings rates and economic growth rates (Bloom and Williamson, 1998; Birdsall, et al. 2001; Mason, 2001). This study by HW is therefore the starting point for my empirical reassessment of the aggregate evidence of the life cycle hypothesis to account for rates of savings within Asian countries. HW estimate the relationship for 16 Asian countries from about 1950 to 1992, using IMF data on savings rates, and Penn World Table (PWT) data on income and prices, and demographic data from United Nations database, in the following form:

$$
\begin{gathered}
S_{t i}=\beta_{1} S_{t-1, i}+\sum_{a=1}^{15} \beta_{2 a} P_{a t i}+\beta_{3} G_{t i}+\beta_{4} R P I_{t i}+\sum_{i=1}^{16} \beta_{5 i} D_{i}+\varepsilon_{t i} \\
\mathrm{t}=1950,1951, \ldots, 1992 ; \quad \mathrm{i}=1,2, \ldots, 16,
\end{gathered}
$$

where $\mathrm{S}_{\mathrm{ti}}$ is the ratio of domestic national savings to GDP in nominal terms in year t for country $\mathrm{i}$; $\mathrm{P}_{\text {ati }}$ is the proportion of the population in age group a (in which $\mathrm{a}=1$ for ages $0-4,=2$ for ages $5-9, \ldots,=14$ for ages $70-74$, $=15$ for ages 75 or more) in year $t$ for country $i$; $G_{t i}$ is annual growth in real GDP in percent from the base of last year, which is expected to raise savings ; RPI ${ }_{t i}$ is the relative price of investment good which should encourage savings (and discourage investment) following DeLong and Summers (1991) drawn from PWT; D are dummy variables equal to one for each country $i$ and zero otherwise, which control for country fixed-effects and capture the effect of time-invariant factors in each country, which would lead to bias if the omitted country factors were correlated with included explanatory variables; $\varepsilon_{\mathrm{ti}}$ is the error in the observed savings rate, due to mis-measurement or approximation in function form, and this error is assumed by HW to be uncorrelated with all of the exogenous explanatory variables.

The unbalanced panel estimates of HW are restricted in other ways. They plausibly assume that economic growth and the relative prices of investment goods are endogenous, and use instrumental variables to estimate their coefficients in a model of savings, where the instruments are lagged explanatory variables and a variety of other current and lagged variables. ${ }^{8}$ Without a strong argument for imposing cross-equation restriction between a savings equation and an investment equation, I report here only their single-equation

\footnotetext{
${ }^{8}$ The instruments include a constant, country dummies Ds, contemporary values of Z1 and Z2 (or Age1 (youth) and Age2 (elderly)), growth of labor force, lagged values of the following: savings rate, investment rate, growth rate, RPI, and growth times Z1, growth times Z2 (or growth times age1 and age2), real gross product per worker in purchasing power parity (PPP) units, real gross product per capita in PPP, openness of the economy defined as exports plus imports as a share of GDP based on national account data, and lagged openness. To improve the explanatory power of the instruments in the first-stage equations, I tried to add a third year of lagged values for growth, RPI, and openness, which improved their joint significance (Bound, et al 1995) without affecting notably the IV point estimates or my conclusions. I also estimated jointly the savings and investment rates. Few changes in the estimated effects of the lagged savings rate or the age composition are notable. This paper presents therefore only the more transparently justified singleequation savings estimates reported by HW (1996, Table 7).
} 
estimates for savings. ${ }^{9}$

\section{Empirical Specification of the Effect of Age Composition on Savings}

There are several issues in estimating the effect of a country's age composition on its savings rate in equation (1). First, because the age composition tends to vary smoothly across ages within a population, the values of $\mathrm{P}_{\text {ati }}$ will be highly correlated across ages, increasing the likelihood that the estimates of the joint effects of specific age classes will be poorly defined due to the multicollinearity. Leff (1969) summarized the age distribution parsimoniously in two parameters by distinguishing three age classes as key to test his hypotheses: the savings effect of a youth dependent class age 0 to 14, and that of an elderly dependent class age 65 or more, thus omitting the labor force aged class age 15 to 64 which are implicitly recovered from the constant term. Modigliani (1970) considers 31 industrialized and Latin American countries and reports the ratio of retired plus youth to working ages. Kelley and Schmidt (1996) included in their preferred "Mason" specification only a single age composition variable for the ratio of youth (age 0-14) to labor force ages (15-64). Bloom, Canning and Graham (2002) modify slightly the age classification of Leff and include the proportion of the population age 0 to 19 (youth) and age 60 and over (elderly) and conclude this specification of the age composition fits their data better than the alternatives. HW adopt a polynomial distribution (using two parameters for a quadratic) approximation as employed by Fair and Dominguez (1991), which smooths the estimated effect of many five year age groups on macro econometric time series estimates analogous to Almond's (1965) method for estimating flexibly distributed lags. However, Fair (1994) subsequently rejects this polynomial parameterization of the age composition as inadequate for his requirements, because it tends to force extreme values on the implied weights it assigns to the lowest and highest age groups, and he adopts instead normalized proportions of the population in fewer age classes. ${ }^{10}$ No study, to my knowledge, addresses the challenge of how to treat age composition as a function of lagged endogenous fertility.

\footnotetext{
${ }^{9}$ The simultaneous estimation of savings and investment has some intuitive appeal, but no additional general equilibrium information is used to motivate the parallel estimates, and presumably to simplify the interpretation of long run responses, HW further restrict the coefficient on the lagged savings and lagged investment to be equal, which is reported as .809 ( $\mathrm{t}=40.3)(1996$, Table 6), whereas in their single-equation unrestricted equations the estimates are, .816 for savings and .824 for investment (1996, Table 7). In general the system and single-equation savings estimates are quite similar.

10 However, whether one adopts the polynomial or discrete age classes in the population to represent distinctive savings behavior, the age variables are highly correlated, and clearly they can only be evaluated jointly. The polynomial quadratic variables called by HW Z1 and Z2 are correlated at -.995 in the Asian sample analyzed here, whereas the Bloom et al (2002) three way age classification leads to the young and elderly proportion variables being correlated in this sample at -.861. In first-differenced form, the correlation between the dZ1 and dZ2 increases to -.997, and for the young/elderly classes d0-19 and d60+ increases to -.921 . I therefore reestimate the model with age classes for the youth and elderly following Bloom and Leff, to facilitate comparisons and test the robustness of the model's alternative specifications of the age composition. HW (1997: Figure 1 notes) report the age shares are expressed in logarithms, but in personal communication with Higgins, he was certain that the estimates were not based on logged age shares. The estimates they report are also hard to decipher if based on logarithms of the age shares.
} 


\section{Estimation of Dynamic Aggregate Relationships}

A second problem for estimating the savings equation (1) as proposed by HW is the inclusion of a lagged dependent variable, in this case the savings rate from the previous year, $\mathrm{S}_{\mathrm{t}-1, \mathrm{i}}$. Savings rates for individuals are expected to gradually adapt to new prevailing conditions, and may not achieve new equilibrium values in precisely a year. The temporal spilling over into the next time period of these adjustments implies that whatever "errors" are present in the savings equation in one year will not be independent of the error in savings in the prior (or following) years. In such a dynamic behavioral relationship it is unrealistic to assume a lagged dependent variable is exogenous or uncorrelated with the contemporaneous error (Nerlove, 1971). HW concludes that the income growth rate, G, and investment prices, RPI, are endogenous and they therefore use instrumental variables to estimate them. But they treat the lagged savings and investment rates as if they were exogenous. ${ }^{11}$ This estimation strategy of HW (X-1) is likely to lead to biased estimates of $\beta_{1}$ and the other parameters, but is replicated here as a benchmark. My second estimates (E-1) therefore treats the lagged savings rate as endogenous. The third specification of model omits the lagged savings rate (N-1), and estimates the same model but in a static form in which savings is assumed to achieve its long run equilibrium value in each period (Cf. Higgins, 1998). A fourth specification assumes a behavioral partial adjustment process and estimates a panel model in first differences (FD-1), which eliminates bias arising from dynamic autoregressive components (Baltagi, 1995; Wooldridge, 2002).

\section{Linear and Quadratic Time Trends in the Pooled Sample and Specific to Countries}

The objective in equation (1) is to estimate the relationship between savings and age composition, both of which variables are trended over time, as illustrated in Figures 2 in various Asian countries. The age composition in a closed population is determined by the historic path followed by crude birth and age-specific death rates. Coale (1972) used stable population methods and demographic simulations of populations to show how the age-specific structure of the decline in death rates affects the age composition. At the start of the demographic transition the declines in mortality are proportionately largest for infants and young children, and the share of the population under age 16 gradually increases. As shown in Figures 2, these shares of youth may rise from about 40 to as much as 45 percent in countries, as seen in Korea and Malaysia. Then as birth rates

${ }^{11}$ Higgins (1998) analyzes savings, investment, and the current account balance across a world sample of 100 countries. There are five notable differences in his model specification from that reported by HW(1997). First, he does not include a lagged dependent variable, implicitly assuming that in five years the adjustment in savings and investment is complete. Second, he treats RPI and $\mathrm{G}$ as exogenous, indicating that it does not change his estimates, which suggests using as instruments the lagged values of RPI and $\mathrm{G}$ does not adequately deal with endogeneity, a worrisome feature of the HW identification strategy. Third, five year averages are analyzed to smooth the volatility in savings and investment rates and dampen errors and shocks of a short-term nature. Fourth, a cubic polynomial approximation for the age composition is specified, rather than a quadratic. He also contrasts the estimates based on within country estimates (i.e. country fixed effects as in HW 1996) and between country estimates, which interestingly are qualitatively similar. He also explores what the effects are on the estimates of assuming the economy is closed, or restricting aggregate savings to equal investments. 
decline, this youth share falls to 25 percent or less. The rise in the dependency burden associated with the onset of the demographic transition and rapid population growth is a transitory burden, followed by a prolonged period of relief (Schultz, 1971). ${ }^{12}$ The initial declines in child mortality and then in fertility tend to proceed irreversibly once they have become established trends, unless new diseases emerge such as HIV/AIDS or dislocating events ensue, such as civil conflict or famine (National Research Council, 2000). ${ }^{13}$ But the mortality and fertility transitions start at different times in different regions and countries, presumably because of differences in initial conditions: institutions, policies, changes in market prices, other environmental conditions and developments (Figure 1). ${ }^{14}$ To attribute confidently a change in savings behavior to another socioeconomic trend such as age composition, it is necessary to show that the bivariate relationship is not due to other development trends. In the case of panel data, where the analysis focuses on explaining changes within each aggregate population, controls should include trends specific to each country. In other words, as a check on the reliability of time series estimates reported by HW, overall time trends and country-specific time trends in linear and quadratic form are added to the savings equation, to confirm that deviations from such trends in savings and age composition are actually behind the estimated relationship reported by HW. If these trends explain the savings association and alter substantially the apparent effects of age composition on savings, the HW specification may be prudently rejected.

\section{New Estimates of Savings Rates for Asian Countries}

Table 1 presents the means and standard deviations of the key variables for the sample of 16 Asian countries for which there is sufficient data to estimate a savings equation for any of the years 1952 to 1992 . I could reconstruct the necessary data for 480 observations in contrast to the HW sample reported of $458 .^{15}$

${ }^{12}$ A second wave of health improvements has more recently reduced death rates in high-income countries, and this time disproportionately reducing deaths among persons over age 50 . These health gains accelerate the growth in the elderly share of the population.

\footnotetext{
${ }^{13}$ More recently the transition in Russia has been associated with a rise in male adult mortality, and the HIV/AIDS epidemic in Africa is contributing to a decline in life expectancy which is due primarily to a rise in middle-age mortality.

14 It may some day be possible to identify specific preconditions in a country (climate and endemic diseases) under which the introduction of a new public health technology (e.g. DDT) makes a large exogenous improvement in child or adult survival (Bloom and Williamson, 1998: Figure 3). To use this information to explain the exogenous timing, pace and age composition of the mortality decline could provide a basis for predicting mortality trends. Forecasting how fertility responds to household and community developments might also suggest instrumental variables predict the time series in fertility. But to use these demographic prediction models to identify the effect of age composition on savings, it would also be necessary to argue that these preconditions determining mortality and fertility do not themselves affect the propensity to save.

${ }^{15}$ When I was unable to replicate the sample size or the HW age estimates, I asked Williamson for a description of their data or a copy, and learned from Higgins that the only copy of the data had been destroyed on September 11, 2001 on Higgins' PC in his Merrill Lynch office in the New York International Trade Center. Higgins could not identify the country-year observations which were used in the published estimates. My sample includes Bangladesh 1976-1992; China 1981-1992; Hong Kong 1966-1992; India 19521992; Indonesia 1966-1992; Japan 1956-1992; Korea 1955-1991; Malaysia 1957-1992; Myanmar 1962-1968, 1975-1989; Nepal 19761986; Pakistan 1961-1992; Philippines 1952-1992; Singapore 1969-1992; Sri Lanka 1952-1992; Taiwan 1956-1990; and Thailand
} 
Column (1) of Table 2 reproduces the original estimates of Higgins and Williamson (1996: Table 7). Column (2) is a replication of their single-equation IV estimates based on their description of their sample, data sources, and statistical methods. Their most controversial assumption, in my view, is that the unexplained error in the current year's savings rates is uncorrelated with the savings rates in the previous year. In other words, they assume that the lagged savings variable can be treated as exogenous to current savings. With the inclusion of country-specific fixed-effects, the Pseudo R square is .94 according to HW, and .91 in my replication. The coefficient on the lagged savings rate is smaller in the replication, .77 compared with .82 , but many times its standard error. ${ }^{16}$ The coefficients on the growth rate are not significantly different from zero. The coefficient estimated on the relative price of investment goods (RPI) is not significant in the replication and a third of the magnitude of the HW estimate. The only estimates HW discuss are the two coefficients on the quadratic polynomial approximation for the effect of the age composition on savings, which are jointly significant according to my estimates $(\mathrm{F}(2,459)=13.4)$ and those reported by $\mathrm{HW}(\mathrm{F}(2,439)=10.7)$. The implied short-run association of saving with the five-year age proportions of the population rise and fall with advancing ages as anticipated in the LC model. However, the magnitude of my estimated effects of the age composition polynomials on savings are roughly one-third the magnitude HW report. When combined with the smaller coefficient on the lagged savings rate, the implied long-run adjustment in savings to the age composition polynomials are four times larger according to HW than in my replication. ${ }^{17}$

When an overall linear or quadratic time trend is added (X-2, X-3), the estimates of Z1 and Z2 remain significant and of roughly the same magnitude in columns (3) and (4) of Table 2. However, when country-

1952-1992. Thus, I am unable to determine how my sample differs from theirs. I also estimated their joint constrained system of savings and investment rates (1996, Table 6), and my estimates of the coefficients on the age polynomial decreased as shown in the single-equation estimates reported in column (2) of my Table 2. One of HW instruments is RGDPW (Real Gross Domestic Product per Worker), which they indicate is from PWT. But the series stops in PWT in 1998, which left me with a sample size of 433 in my first estimates. Labor force growth from 1989 to 1992 is therefore drawn from the World Bank Development Indicators to complete the series for RGDPW for most countries.

${ }^{16}$ Fry and Mason (1982), Mason (1987), and Kelley and Schmidt (1996) include in their model interactions between income growth and the age composition. HW do not adopt this specification because, they argue, it is derived from a steady-state growth model and ignores the important disequilibrium consequences of changing age compositions. Including in my estimates interactions between $\mathrm{G}$ and age composition polynomials or age classes was not a general improvement, although I followed HW and included the interactions in the list of instruments.

${ }^{17}$ One reason for specifying models of demand or supply with a lagged dependent variable is that technical and institutional rigidities are expected to delay full adjustment and temporally distribute the adjustment in an exponentially lagged form (Koyck, 1954; Almond, 1965; Balestra and Nerlove, 1966). In such a framework the short run effect of a change in the age composition on savings is represented in equation (1) by $\beta_{2}$, whereas in the long run the feedback each period transmitted through the lagged dependent variable accumulates until the long run effect of age composition on saving reaches $\beta_{2} /\left(1-\beta_{1}\right)$. HW estimates in Table 2 imply a .01 decrease in the share of children age 0-4 (average in sample .13) and an offsetting increase in the share of persons age 15-19 (or 60-64) who appear to have a relatively neutral effect on savings would be associated with a .011 increase in the proportion of income saved in the following year (short run)(See figure 3). This effect would gradually increase 5.4 fold in the long run (i.e., $\beta_{2} /(1-.816)$ ), and according to the HW estimates, the long run effect on savings would be about .060 . My replication estimate suggests a much smaller impact on savings in both the short run and long run. 
specific linear trends are included, these country-specific trend parameters are themselves highly significant $(\mathrm{F}(16,443)=4.99, \mathrm{p}<.0000)$, and the estimated long term effect of the age composition on savings decreases by another two-thirds. Are other linear trended variables within these developing Asian countries accounting for the broad trends in savings rates, or is it reasonable to attribute these trends only to changes in age composition, as concluded in the papers on the "demographic dividend" (Bloom and Williamson, 1998; Birdsall, et al, 2001; Mason, 2001)? If not, the estimated long run effects of the age composition controlling for country-specific trends are only about one-tenth the magnitude of those extrapolated by HW in their simulations.

Based on the instruments listed in HW to identify the savings effects of growth and investment prices, the Durbin-Wu-Hausman specification test rejects the hypothesis that the lagged savings rate is exogenous at a 1 percent confidence level reported at the bottom of column 1 of Table 3 . The preferred specification is thus estimated in Table 3 that treat the lagged savings rate as endogenous (E-1) without trends in the first column of Table 3. In this case, the estimated coefficients on Z1 and Z2 are no longer jointly statistically different from zero, and the magnitude of the imprecise point estimates are about one-third of those in the replicated model in which lagged savings is assumed exogenous (X-1 in Table 2). Figure 3 visually contrasts the implied estimates of the age polynomial for the 15 age groups across specifications. The age group estimates (diamonds) reported by Higgins and Williamson (1996, Figure 1), are compared with the replication estimates (squares) with the lagged dependent variable (LDV) treated as exogenous, and finally with the preferred estimates (triangles) where the LDV are treated as endogenous, excluding any time trends.

If the endogenous lagged savings estimates do not provide convincing evidence of dynamic adjustment behavior, this may explain why Higgins (1998) estimated a static model of savings, in which he omits altogether the lagged savings rate. Estimates of this static specification are reported in columns (7), (8), and (9) in Table 2. When no time trends is specified in column $(7)(\mathrm{N}-1)$, the age composition polynomial coefficients are jointly significant, and the savings effects of age are of approximately the same magnitude as the long-term effects derived from the exogenous lagged savings estimates in column (2) in Table 2 (X-1). Including quadratic country specific trends in column (9) (N-5) decreases the age composition effects by about the same two-thirds as in the LDV exogenous specification (X-5). Again, the evidence is that if flexible time trends in savings are allowed to vary by country, the age composition exerts little effect on savings.

The final strategy for estimating a dynamic adjustment model from panel data involves taking first differences of all of the variables, or their changes over time, to purge the estimates of bias caused by correlations between the individual country persistent factors and the explanatory variables. I have used levels 
in the lagged variables as instruments for the endogenous growth, RPI and lagged savings. ${ }^{18}$ The estimates of this first-differenced (FD) model are reported in Table 4, which is analogous to that estimated in Tables 2 and 3. If trends in savings are ignored as in (E-1) the first differences (FD-1) require that the constant term be suppressed. Including the constant term in (FD-2) implicitly allows for an overall linear time trend in the savings. Correspondingly, (FD-3) includes a quadratic overall trend, and (FD-4) and (FD-5) include the country-specific linear and quadratic trends. When the effect on saving of lagged savings is purged of the possible correlation between the savings error and the individual country fixed effects, there remains no significant association between the age composition and current savings ( $F(2,464=.43$ in column 1 Table 4$)$, with or without trends.

Perhaps the age polynomial is not summarizing adequately the effect of the age composition on savings, as argued by Fair (1994). The more straightforward measures of the proportion of the population who are youth-- age 0-19 -- and elderly -- age 60 or over -- could better represent the savings effect of these two dependent age groups. ${ }^{19}$ Estimates of this specification of the savings equation are reported in Table 5 in which lagged savings is first treated as exogenous, and then it is treated as endogenous with different time trends in what is my preferred specifications. The first column $(\mathrm{X}-1)$ is based on the HW assumption that lagged savings is exogenous, which is rejected again by the Hausman specification test (not reported). The two age class variables are in this case significant at the .02 percent level, and they explain marginally less of the variation in savings than the quadratic polynomial, with the Pseudo R squared adjusted for degrees of freedom being .903 in Table 5, compared with .910 in Table 2. A decrease in the youth share by .01 is associated with an increase in savings by .0024 , and a comparable decrease in the smaller elderly share (Cf. Table 1) is associated with an increase in savings by .0044 . When lagged savings is estimated as endogenous in the second column of Table 5 the short run effect drops to less than half it prior value, the "adjustment" coefficient on lagged savings is .95 implying a very long adjustment of savings, but the age-category variables are not jointly statistically significant. Adding overall time trends or country-specific trends does not improve the significance of the age composition variables. Changing the representation of the age composition from the quadratic polynomial approximation to the two dependent age groups does not alter in any fundamental way these findings. The Hausman specification tests rejects the exogeneity of savings given the HW instruments, and if savings are thus

${ }^{18}$ For the early use of panel data see Balestra and Nerlove (1966), the exploration of general estimation approaches by Nerlove (1971), and more recent methods for dealing with these problems by Baltagi (1995) and Wooldridge (2002).

${ }^{19}$ Estimates were also obtained considering the ages 0 to 14 and 65 and over, which were somewhat less significant jointly than the larger dependent group variables reported in Table 5. No notable changes in conclusions were noted from these alternative age groups, or for that matter when a third category of prime saving age is included, or when the youth and elderly are expressed as a fraction of the prime aged population, or a cubic polynomial in age is included as in Higgins (1998). 
viewed as endogenous, there is no statistical reason to conclude from these aggregate estimates that the age composition is significantly related to the aggregate savings rates within Asian countries.

\section{Directions for Future Empirical Research on Savings and the Demographic Transition}

To understand how changes in the age composition of Asian countries might affect savings and growth opportunities, I would propose several directions for further research: (1) reexamine aggregate relationships between the demographic transition and savings, in which the age composition is endogenous and estimated with suitable instrumental variables which are outside the control of the family and which are likely to have affected past trends in fertility as well as child mortality; (2) analyze individual, household, and intergenerational family data to describe causal mechanisms linking the family's lifetime environment to fertility, time allocation, human capital investments, and physical savings over a lifetime; (3) expand the sample of countries analyzed beyond Asia, and include the preconditions and institutional settings which may affect the incentives for families to have children and to accumulate physical wealth; and (4) if older populations demand more pensions and medical care, consider how these expenditures can be supported by non-distortionary taxes and household resources, to avoid running public deficits which could crowd-out productive investments.

The first direction for research would reexamine aggregate panel data for countries, but extend the analysis to account for the timing and speed of the demographic transition and thereby treat the age composition as if it were dependent on family lifetime behavior. A country's current age composition is a reflection of past family fertility decisions, which are coordinated with the allocation of mother's time, the allocation of resources to child health and schooling, and savings in the form of physical assets. Higgins and Williamson (1996) specify instruments to predict growth and relative prices which are arguably endogenous to family life cycle behavior, such as labor force participation, the age composition, and lagged savings. Selecting the instruments to determine birth and death rates might refocus analysis on the policy interventions and institutions that have governed the timing of the demographic transition in different countries. For example, the historic path of child mortality might be partly explained by when public health programs in a country adopt new technologies, such as vaccination programs and family planning methods, and the effectiveness of these interventions in the context of the local climate with its specific endemic disease vectors. But these public sector interventions are only part of the process. The health management capacity of families should also be considered, and the most readily distinguished factor affecting the health of children is the education of mothers, as well as the income opportunities and inequalities between families, the relative price of foodstuff and volatility of these prices, urban transmission of communicable diseases, public and private health services in rural and urban areas, and urban and rural infrastructure providing safe water supplies, sanitation, and electricity. 
Declines in fertility are linked at the family and aggregate levels to the increasing schooling of young women, as well as the increasing local employment opportunities for women outside of the home, access to reliable birth control, and the empowerment of women measured by their education, employment, and assets relative to that of men in society, and women's property rights to dispose of their assets, to use them as collateral for credit, and to share in family inheritance. The increasing labor force participation of women outside of the home, which is evident in many parts of the world, is closely associated to the decline in fertility. Women's entry into work outside of the home, however, is not a necessary consequence of fertility decline; cultural and labor market institutions influence when women are drawn into the labor force, what types of jobs they occupy, and whether they compete with or supplement male workers. All of these local conditions and labor market institutions also affect fertility and probably strengthen the capacity of governments or NGOs to deliver family planning methods directly to women. These gender related social developments differ not only across Eastern Asia between Japan, Korea, and Taiwan and Singapore, but even more notably across South Asia from Sri Lanka, Bangladesh, India, Pakistan, to Nepal.

A second direction for research would be to model explicitly fertility as a life cycle choice, and estimate how the decline in fertility is determined within and across birth cohorts, and how policy induced changes in child mortality and fertility are associated with savings and asset accumulations at the individual level. Following birth cohorts over time in repeated cross sectional surveys, it should be possible to decompose change in aggregate outcomes for a cohort into change due to micro determinants. This approach could test the predictions of micro behavioral models only if the determinants of fertility, child mortality, and savings are specified in terms of variables that are beyond the control of families or exogenous. As hypothesized earlier, different causes for the decline in fertility are likely to have different "cross-effects" on household savings, and the schooling and health of children, as well as the capacity of children to migrate to regions where employment opportunities are better. ${ }^{20}$ In other words, unless one is able to distinguish (i.e. identify) the background causes for the fertility decline, it is hard to test the validity of life cycle saving hypothesis and assess whether it "adds up" to the "demographic dividend" or is due to other unobserved factors. More family level research on these issues is needed, guided by the distinction between exogenous constraints on the family and of endogenous lifetime choices by the family (Schultz, 1981). Understanding the causes for fertility decline, and the

${ }^{20}$ Hammer (1986) estimated parallel reduced-form equations for household fertility and savings, recognizing they were likely to be coordinated family behaviors, and documented opposite effects of household constraints on the two outcomes. Mason (1987: pp.539-540) concludes upon reviewing the evidence from aggregate country studies of the demographic dividend model:" by failing to model explicitly the "instruments" by which fertility and, hence, the dependency ratio change, the model estimated above has limited policy applications. On theoretical grounds, the effect of reduced fertility on aggregate saving ratio should vary depending on the means by which a fertility reduction is achieved: fertility decline accomplished via non price policies unambiguously reduces the share devoted to childrearing and increases aggregate saving; fertility decline induced via price changes has an ambiguous impact on saving that depends on the elasticity of demand". 
simultaneous child mortality decline, that are outside of the family's control, should also help in evaluating how public health initiatives, family planning programs, childhood immunization campaigns, reproductive health programs, and other specific reproductive and child health policies have each contributed to improve the well being of individuals.

A third direction for research would be to extend the analysis beyond Asia. Asia is an attractive initial setting for such studies, because the decline in child mortality and fertility starts first in North East Asia, follows in South East Asia, and occurs more gradually in Central and West Asia as seen in Figure 1. I would be surprised if Asian patterns of savings and growth emerge in sub-Saharan Africa, because the region's fertility is only beginning to decline, and because other conditions in the African region are unfavorable for growth, including civil conflict, refugee movements, and the HIV/AIDS epidemic. But Latin America presents an interesting puzzle and challenge to the hypothesized "demographic dividend", and its distinctive behavior should be a focus of more research. A more comprehensive micro theory of household savings than the lifecycle hypothesis might help to account for Latin America. Specifically, why did the early fertility decline in Latin America fail to trigger an increase in private savings (Ahlburg, 2002)? Were financial institutions repressed or geared to serve primarily upper income classes in Latin America, where credit markets were often distorted by inflation and government regulations? Did the poor in Latin America enjoy fewer opportunities to invest in the schooling of their children, or were the private wage returns from such schooling demonstrably lower than those enjoyed by the poor in Asia? Did the protection from international trade in Latin America restrict the growth of export-oriented industries, industries which in Asia provided employment opportunities for many women. In other words, what conditions in Latin America made it less advantageous for parents, as they voluntarily restricted their fertility starting in the 1960 s, to substitute physical savings and human capital investments for number of children? I have not seen empirical evidence to explain the experience of Latin America.

\section{Have We Made Progress: Tentative Conclusions}

The partial association between savings and the quadratic polynomial approximation for the age structure appears to be statistically significant when conditioned on lagged savings, if this lagged dependent variable is treated as exogenous. But this treatment of a lagged dependent variable as exogenous in an adaptive behavioral model of savings is implausible, both conceptually in a macro economic model, and empirically according to a Hausman test of exogeneity reported in Table 3. The long-run effect of the age composition on savings, under the hypothetical assumption that it is exogenous, is a fourth the magnitude reported by Higgins and Williamson (HW,1996, 1997). Instead of attributing a third of the increase in Asian savings and growth in this period to the exogenous change in the age composition, as HW do, my estimate in Table 2 (X-1) accounts 
for a tenth of the rise in Asian savings rates, according to their calculations. When linear time trends are introduced, which are allowed to vary for each country, the estimated effect of the age composition on savings is reduced by another two-thirds. But as noted, conceptual and empirical evidence suggests the need to reestimate the dynamic savings model and treat lagged savings as an endogenous variable, identified by the HW instruments (E-1, Table 3). The joint effects of the age composition parameters are then statistically insignificant, whether approximated by the quadratic polynomial function used by HW, or the three age classes in Table 5 as used by Bloom et al (2002). Including time trends specific to each country, a common practice in panel data studies to check the robustness of estimates, the age composition has unstable and imprecise effects on savings. Finally, if the model is estimated in first differences to remove bias from dynamic autoregressive components, the age composition effects on savings appear to be statistically insignificant.

There is a time trend in the glacial evolution of the age composition within these 16 Asian countries from 1950 to 1992 which is superficially related to the time trend in increasing savings rates (Figures 2). Implementing a variety of econometric methods to estimate the dynamic effect of age composition on aggregate savings does not uncover stable empirical support for the conclusion that the secular rise in savings in these countries during this period depends on the increase in the proportion of these populations entering the prime working ages of 20 to 59 when savings is expected to be higher than average.

\section{Learning From Chinese Experience}

Modigliani crystalized the implications of savings as a life cycle behavior fifty years ago, and his recent study of Chinese savings illustrates again the intuitive appeal and statistical limitations of this framework to fit aggregate time series (Modigliani and Cao, 2004). The Asian sample of countries which HW study and I have analyzed in this paper is based on IMF saving data published by 1995, and therefore only includes observations for China for 1981 to 1992. Modigliani and Cao (2004) have estimated Chinese savings data for 1953 to 2000 , when savings out of disposable income increased from 5 to 35 percent from 1975 to1995. They account for most of the annual variation in savings by regressing it on two variables suggested by the life cycle model: long-term income growth (over the last 15 years), and the ratio of dependent youth to employed workers. Their

evidence warrants a skeptical evaluation. Others have not found the expected life cycle pattern in household savings within other Asian or high-income countries (Browning and Lusardi, 1996; Deaton and Paxson, 1997; Schultz, 1998). Household studies of savings behavior for China are now needed to advance Modigliani's interpretation of the time series aggregate association.

Modigliani and Cao (2004, p. 151) also see the implications of the household demand model, as they note that "a child is an effective substitute for life cycle savings. Consequently, when strict birth control 
measures came into effect in the 1970s (i.e., one-child family population policy in China) the accumulation of life cycle (tangible) assets gains in importance as a substitute for children." If children and savings are substitutes, the life cycle savings framework should incorporate the household demand for children and other assets to explain more comprehensively savings behavior. To test this more comprehensive model of household lifetime savings and the demographic transition, data are needed for intergenerational families that survey both generations, to document transfers in both directions and savings and reproduction. Inter-generational transfers and exchanges are potentially important and a neglected aspect of consumption-smoothing behavior in poor countries. The association within countries over time of savings and age composition is suggestive of a causal relationship, but is not firm evidence of a relationship which can be extrapolated beyond the period observed into a future, older Asia, or for that matter extended to developments unfolding in other regions of the world, such as Africa.

Two influential economic models have assumed population growth and structure are driving forces in development. Malthus postulated that natural propensities toward population growth would neutralize any real wage gains accruing to the working class in the long run. His insights have structured our thinking about the industrial revolution for two centuries, and reinforced a pessimistic view of the consequences of the demographic transition in the low-income world, especially in China and India (Coale and Hoover, 1958). Modigliani's life cycle savings hypothesis is also emerging today as a forecasting tool which implies savings will decline as a country ages, slowing its potential for economic growth. However, both frameworks neglect the adaptive capacity of economic and social institutions in a changing world, including most centrally the role of the family to reallocate resources, and to coordinate lifetime behavior and living arrangements to improve the well being of its members. As life becomes healthier and longer, women become better educated and more productive, and fertility declines, the behavior of the family will probably adapt to the changing age composition of its membership to realize the gains and distribute the burdens. How this will impact the aggregate rate of savings of physical and human capital remains to be seen.

\section{$\underline{\text { References }}$}

Ahlburg, D.A., 2002, "Does Population Matter? A Review Essay”, Population and Development Review, 28(2): 329-350.

Angrist, J.A., G.W. Imbens, and D.B. Rubins, 1996, "Identification of Causal Effects Using Instrumental Variables", Journal of the American Statistical Association, 91: 444-472.

Almond, S., 1965, "The Distributed Lag Between Capital Appropriations and Expenditures," Econometrica 33(1): 178-196. 
Balestra, P. and M. Nerlove, 1966, "Pooling Cross Section and Time Sources Data in the Estimation of a Dynamic Model,” Econometrica, 34(3):385-412.

Baltagi, B.H., 1995, Econometric Analysis of Panel Data, New York: Wiley.

Becker, G.S., 1981, A Treatise on the Family, Cambridge MA: Harvard University Press.

Bhalla, Surjit S., 2002, Imagine There is no Country, Washington D.C. : Institute for International Economics

Birdsall, N., A.C. Kelley and S.W. Sinding (eds), 2001, Population Matters, Oxford: Oxford University Press.

Bloom, D., D. Canning and B. Graham, 2002, "Life Expectancy and National Saving Rates," Harvard School of Public Health, Boston, MA.

Bloom, D.E. and J.G. Williamson, 1998, "Demographic Transition and Economic Miracles in Emerging Asia", World Bank Economic Review, 12(3): 419-455.

Bound, J., D. A. Jaeger, R. M. Baker, 1995, "Problems with Instrumental variable estimation when the correlation between the Instruments and Endogenous explanatory variables is Weak," Journal of the American Statistical Association, 90 (430): 443-450.

Browning M., 1992, "Children and Household Economic Behavior," Journal of Economic Literature 30(3):1434-75.

Browning, M. and A. Lusardi, 1996, "Household Savings: Micro Theories and Micro Facts," Journal of Economic Literature 34(4): 1797-1855.

Carroll, C.D. and L.J. Summers, 1991, "Consumption Growth Parallels Income Growth,” in National Savings and Economic Performance, B.D. Bernheim and J.B. Shoven, Chicago: University of Chicago Press, pp. 305-43.

Coale, A.J., 1972, The Growth and Structure of Human Populations, Princeton, NJ: Princeton University Press.

Coale, A.J. and E.M. Hoover, 1958, Population Growth and Economic Development in Low Income Countries, Princeton, NJ: Princeton University Press.

Deaton, A., 1997, The Analysis of Household Surveys, Baltimore, MD: Johns Hopkins University Press, pp. $80-85$.

Deaton, A., 2003, "Measuring Poverty in a Growing World (or measuring growth in a poor world)", Working Paper w9822, Cambridge MA: National Bureau of Economic Research.

Deaton, A.S. and C. H. Paxson, 1997, "The Effects of Economic and Population Growth on National Saving and Inequality", Demography, 34(1): 97-114.

Delong, J.B. and L.H. Summers, 1991, Equipment Investment and Economic Growth," Quarterly Journal of Economics, 106:445-502.

Fair, R.C., 1994, Testing Macroeconometric Models, Cambridge, MA: Harvard University Press. 
Fair, R.C. and K.M. Dominguez, 1991, "Effects of the Changing U.S. Age Distribution on Macroeconomic Equations," American Economic Review 81(5):1276-1294.

Friedman, M., 1957, A Theory of the Consumption Function, Princeton NJ: Princeton University Press.

Fry, M.J. and A. Mason, 1982, "The Variable Rate of Growth Effect of the Life Cycle Savings Model," Economic Enquiry 20:426-442.

Hammer, J.S., 1986, "Children and Savings in Less Developed Countries," Journal of Development Economics, 23:107-118.

Heller, P.S., 2003, Who Will Pay? Coping with Aging Societies, Climate Change and other Long-term Fiscal Challenges, International Monetary Fund, Washington, DC.

Higgins, M., 1998, "Demography, National Savings, and International Capital Flows," International Economic Review, 39 (2): 343-369.

Higgins, M. and J.G. Williamson, 1996, "Asian Demography and Foreign Capital Dependence," NBER Working Paper No. 5560, Cambridge, MA: National Bureau of Economic Research.

Higgins, M. and J.G. Williamson, 1997, "Age Structure Dynamics in Asia and Dependence on Foreign Capital," Population and Development Review, 23(2):261-293.

Johnson, D.G., 1999, "Population and Development," China Economic Review, 10(1):1-16.

Jorgenson, D.W., 1995, Productivity, Volume 1, Postwar U.S. Economic Growth, Chapters 6-8, Cambridge, MA: MIT Press.

Kelley, A.C. and R.M. Schmidt, 1996, "Saving, Dependency and Development," Journal of Population Economics, 9(4):365-386.

Kotlikoff, L.J., 1988, "Intergenerational Transfers and Savings," Journal of Economic Perspectives, 2(1):4158.

Koyck, L.M., 1954, Distributed Lags and Investment Analysis, Amsterdam: North Holland.

Lee, R.D. and S. Lapkoff, 1988, "Intergenerational Flows of Time and Goods: Consequences of Slowing Population Growth," Journal of Political Economy 96(3):618-651.

Leff, N.H., 1969, “Dependency Rates and Savings Rates,” American Economic Review, 59(5):886-896.

Lewis, F.D., 1983, "Fertility and Savings in the United States: 1830-1900," Journal of Political Economy, 91(5):825-840.

Mason, A., 1987, "National Savings Rates and Population Growth" in D.G. Johnson and R.D. Lee (eds) Population Growth and Economic Development, Madison WI: University of Wisconsin Press.

Mason, A. (ed), 2001, Population Change and Economic Development in East Asia, Stanford, CA: Stanford University Press. 
Mincer, J., 1963, "Market Prices, Opportunity Costs and Income Effects", in Measurement in Economics, C. Christ, et al (eds), Stanford CA: Stanford University Press.

Modigliani, F., 1970, "The Life Cycle Hypothesis of Savings and the Intercountry Differences in the Savings Ratio," Induction, Growth and Trade: Essays in Honor of Sir Roy Harrod, W.A. Eltis, M.F.G. Scott, J.N. Wolfe (eds), Oxford: Clarendon Press.

Modigliani, F. and R. Brumburg, 1954, "Utility Analysis and the Consumption Function," Chapter 15, in Post

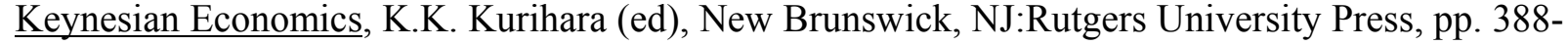
436.

Modigliani, F., and S.L. Cao, 2004, "The Chinese Savings Puzzle and the Life Cycle Analysis," Journal of Economic Literature, 42(1): 145-170.

National Research Council, 2000, Beyond Six Billion, J. Bongaarts and R.A. Bulatao (eds), Washington, DC: National Academies Press.

Nerlove, M. , 1971, "Further Evidence on the Estimation of Dynamic Economic Relations from a Time Series of Cross Sections", Econometrica, 39: 383-96.

Paxson, C., 1996, "Savings and Growth: Evidence from Microdata," European Economic Review, 40:255-288.

Rosenzweig, M.R. and T.P. Schultz, 1987, "Fertility and Investment in Human Capital", $\underline{\text { Journal of }}$ Econometrics, 36: 163-184.

Rosenzweig, M., and K. Wolpin, 1980a, "Testing the Quality-Quantity Fertility Model," Econometrica, 48(1):227-240.

Rosenzweig, M.R. and K.I. Wolpin, 1980b, "Life Cycle Labor Supply and Fertility: Causal Inferences from Household Models," Journal of Political Economy 88(2):3278-348.

Samuelson, P.A., 1958, "An Exact Consumption Loan Model of Interest With or Without the Contrivance of Money," Journal of Political Economy, 66(6):467-482.

Schultz, T.P., 1971, “An Economic Perspective on Population Growth,” in Rapid Population Growth, National Academy of Science, Baltimore, MD: Johns Hopkins University Press.

Schultz, T.P., 1981, Economics of Population, Reading, MA: Addison-Wesley.

Schultz, T.P., 1998, "Life Cycle Savings, Choice of Family Composition and the Demographic Transition," paper presented at the European Society for Population Economics meetings, June 3-5, 1998, Amsterdam.

Schultz, T.P., 1999, "Who is a Household Head?" presented at European Society for Population Economics Meetings, Turin, Italy, June 16.

Schultz, T.P., 2002, "Fertility Transition: Economic Explanations," International Encyclopedia of the Social and Behavioral Sciences, N.J. Smelser and P.B. Baltes (eds), Oxford, UK: Pergamon Press, pp. 5578-5584. 
Schultz, T.P., 2004, "Human Resources in China: The Birth Quota Returns to Schooling and Migration," Pacific Economic Review, 9(3) : 245-67. (Yale University Economic Growth Center Discussion Paper No. 855)

Taylor, A. and J.G. Williamson, 1994, "Capital Flows to the New World as an Intergenerational Transfer," Journal of Political Economy, 102(2):348-369.

Tobin, J., 1967, "Life Cycle Savings and Balanced Growth," Chapter 9 in Ten Economic Studies in the Tradition of Irving Fisher, W. Fellner, et al. (eds), New York, NY: Wiley, pp. 231-256.

Tobin, J. and H. Houthakker, 1950-51, "The Effects of Rationing on Demand Elasticities," Review of Economic Studies, 18(3):140-153.

United Nations, 2003, World Population Prospects: The 2002 Revision, Vol. I , Department of Economic and Social Affairs, Population Division, New York: United Nations.

Wooldridge, J.M., 2002, Econometric Analysis of Cross Section and Panel Data, Cambridge, MA: MIT Press. 
Table 1

Sample Statistics for Asian Countries Available from 1952 to 1992: Sample Size $480^{\mathrm{a}}$

\begin{tabular}{|l|l|}
\hline Variable & Levels \\
\hline Savings Rate & .209 \\
& $(.102)$ \\
\hline Investment Rate & .234 \\
& $(.0851)$ \\
\hline $\begin{array}{l}\text { Growth GDP Last Year } \\
\text { (Proportion) }\end{array}$ & .0627 \\
\hline $\begin{array}{l}\text { Relative Price of } \\
\text { Investment Goods }\end{array}$ & \begin{tabular}{l}
$.0509)$ \\
\hline $\begin{array}{l}\text { Openness of Economy } \\
\text { (percent) }\end{array}$
\end{tabular} \\
\hline $\begin{array}{l}\text { Z 1 } \\
\text { (quadratic polynomial) }\end{array}$ & $\begin{array}{l}(.680) \\
(75.8)\end{array}$ \\
\hline $\begin{array}{l}\text { Z 2 } \\
\text { (quadratic polynomial) }\end{array}$ & $\begin{array}{l}-2.45 \\
(.646)\end{array}$ \\
\hline $\begin{array}{l}\text { Young (0-19) } \\
\text { proportion }\end{array}$ & $\begin{array}{l}-37.5 \\
(8.62)\end{array}$ \\
\hline $\begin{array}{l}\text { Elderly (60 or more) } \\
\text { proportion }\end{array}$ & .481 \\
\hline $\begin{array}{l}\text { GDP } \\
\text { per capita }\end{array}$ & $(.0746)$ \\
\hline $\begin{array}{l}\text { GDP } \\
\text { per worker }\end{array}$ & $\begin{array}{l}.0649 \\
(.0212)\end{array}$ \\
\hline & $\begin{array}{l}(2998 .) \\
(4918 .)\end{array}$ \\
\hline
\end{tabular}

a Means are shown and standard deviation is reported in parenthesis below the mean. 


\begin{tabular}{|c|c|c|c|c|c|c|c|c|c|}
\hline \multirow{3}{*}{$\begin{array}{l}\text { Explanatory } \\
\text { Variables }\end{array}$} & \multirow{2}{*}{$\begin{array}{l}\text { Higgins\& } \\
\text { Williamson } \\
\text { (1996, Table 7) }\end{array}$} & \multirow{2}{*}{$\begin{array}{l}\text { Approximate } \\
\text { Replication } \\
(\mathrm{X}-1)\end{array}$} & \multirow{2}{*}{$\begin{array}{l}\text { Linear } \\
\text { Time } \\
\text { Trend } \\
(\mathrm{X}-2)\end{array}$} & \multirow{2}{*}{$\begin{array}{l}\text { Quadratic } \\
\text { Time Trend } \\
\text { (X-3) }\end{array}$} & \multicolumn{2}{|c|}{$\begin{array}{l}\text { Country Specific } \\
\text { Trends }\end{array}$} & \multicolumn{3}{|c|}{ No Lagged Savings Variable } \\
\hline & & & & & $\begin{array}{l}\text { Linear } \\
\text { (X-4) }\end{array}$ & $\begin{array}{l}\text { Quadratic } \\
\text { (X-5) }\end{array}$ & $\begin{array}{l}\text { No Trend } \\
(\mathrm{N}-1)\end{array}$ & $\begin{array}{l}\text { Quadratic } \\
\text { Trend } \\
(\mathrm{N}-3)\end{array}$ & $\begin{array}{l}\text { Country Specific } \\
\text { Quadratic Trend } \\
\text { (N-5) }\end{array}$ \\
\hline & (1) & $(2)$ & (3) & (4) & (5) & (6) & (7) & (8) & (9) \\
\hline Lagged Savings & $\begin{array}{l}.816 \\
(28.3)\end{array}$ & $\begin{array}{l}.770 \\
(16.1)\end{array}$ & $\begin{array}{l}.750 \\
(15.1)\end{array}$ & $\begin{array}{l}.728 \\
(14.4)\end{array}$ & $\begin{array}{l}.397 \\
(6.35)\end{array}$ & $\begin{array}{l}.331 \\
(5.51)\end{array}$ & -- & -- & -- \\
\hline Growth & $\begin{array}{l}-.0446 \\
(.50)\end{array}$ & $\begin{array}{l}-.218 \\
(1.25)\end{array}$ & $\begin{array}{l}-.141 \\
(.80)\end{array}$ & $\begin{array}{l}-.140 \\
(.79)\end{array}$ & $\begin{array}{l}.200 \\
(1.43)\end{array}$ & $\begin{array}{l}.0734 \\
(.74)\end{array}$ & $\begin{array}{l}-.790 \\
(2.28)\end{array}$ & $\begin{array}{l}-.364 \\
(1.23)\end{array}$ & $\begin{array}{l}-.0314 \\
(.28)\end{array}$ \\
\hline RPI & $\begin{array}{l}.0442 \\
(2.47)\end{array}$ & $\begin{array}{l}.0145 \\
(1.56)\end{array}$ & $\begin{array}{l}.0174 \\
(1.90)\end{array}$ & $\begin{array}{l}.0242 \\
(2.58)\end{array}$ & $\begin{array}{l}.0715 \\
(3.27)\end{array}$ & $\begin{array}{l}.0800 \\
(2.72)\end{array}$ & $\begin{array}{l}.0384 \\
(2.09)\end{array}$ & $\begin{array}{l}.0685 \\
(4.23)\end{array}$ & $\begin{array}{l}.101 \\
(2.95)\end{array}$ \\
\hline Z 1 & $\begin{array}{l}.690 \\
(3.24)\end{array}$ & $\begin{array}{l}.202 \\
(4.92)\end{array}$ & $\begin{array}{l}.176 \\
(4.50)\end{array}$ & $\begin{array}{l}.213 \\
(4.92)\end{array}$ & $\begin{array}{l}.182 \\
(2.51)\end{array}$ & $\begin{array}{l}.208 \\
(1.75)\end{array}$ & $\begin{array}{l}.812 \\
(12.6)\end{array}$ & $\begin{array}{l}.714 \\
(11.0)\end{array}$ & $\begin{array}{l}.378 \\
(2.56)\end{array}$ \\
\hline Z2 & $\begin{array}{l}-.0458 \\
(2.78)\end{array}$ & $\begin{array}{l}-.0134 \\
(4.56)\end{array}$ & $\begin{array}{l}-.0117 \\
(4.25)\end{array}$ & $\begin{array}{l}-.0135 \\
(4.53)\end{array}$ & $\begin{array}{l}-.0160 \\
(2.74)\end{array}$ & $\begin{array}{l}-.0060 \\
(.60)\end{array}$ & $\begin{array}{l}-.0528 \\
(10.6)\end{array}$ & $\begin{array}{l}-.0448 \\
(9.71)\end{array}$ & $\begin{array}{l}-.0154 \\
(1.22)\end{array}$ \\
\hline $\begin{array}{l}\text { Year (linear) } \\
\left(\times 10^{-2}\right)\end{array}$ & & & $\begin{array}{l}.0371 \\
(1.49)\end{array}$ & $\begin{array}{l}.246 \\
(3.61)\end{array}$ & -- & -- & $\begin{array}{l}.716 \\
(7.01)\end{array}$ & & -- \\
\hline $\begin{array}{l}\text { Year Squared } \\
\left(\times 10^{-4}\right)\end{array}$ & & & & $\begin{array}{l}.465 \\
(3.39)\end{array}$ & & -- & $\begin{array}{l}-1.30 \\
(5.74)\end{array}$ & & -- \\
\hline Pseudo $\mathrm{R}^{2}$ & .937 & .910 & .919 & .921 & .937 & .946 & .650 & .804 & .930 \\
\hline Observations & 458 & 469 & 433 & 433 & 433 & 433 & 468 & 433 & 433 \\
\hline $\begin{array}{l}\text { Joint Significance of } F \\
\text { Test Age Composition }\end{array}$ & $\begin{array}{l}(2,439) \\
=10.72 \\
p>.001\end{array}$ & $\begin{array}{l}(2,459) \\
=13.4 \\
p>.0000\end{array}$ & $\begin{array}{l}(2,458) \\
=10.6 \\
p>.000\end{array}$ & $\begin{array}{l}(2,457) \\
=13.6 \\
p>.0000\end{array}$ & $\begin{array}{l}(2,443) \\
=4.43 \\
p>.015\end{array}$ & $\begin{array}{l}(2,427) \\
=5.06 \\
p>.0056\end{array}$ & $\begin{array}{l}(2,460) \\
=151 \\
p>.0000\end{array}$ & $\begin{array}{l}(2,458) \\
=80.3 \\
p>.0000\end{array}$ & $\begin{array}{l}(2,428) \\
=9.08 \\
p>.0001\end{array}$ \\
\hline $\begin{array}{l}\text { Country Specific } \\
\text { Trend: } \\
\text { Year (linear) } \\
\text { Year Squared }\end{array}$ & $\begin{array}{l}\text { no } \\
\text { no }\end{array}$ & $\begin{array}{l}\text { no } \\
\text { no }\end{array}$ & $\begin{array}{l}\text { no } \\
\text { no }\end{array}$ & $\begin{array}{l}\text { no } \\
\text { no }\end{array}$ & $\begin{array}{l}\text { Yes } \\
p>.000 \\
\text { No }\end{array}$ & $\begin{array}{l}\text { Yes } \\
\text { Yes } \\
p>.0000\end{array}$ & $\begin{array}{l}\text { no } \\
\text { no }\end{array}$ & $\begin{array}{l}\text { no } \\
\text { no }\end{array}$ & $\begin{array}{l}\text { Yes } \\
\text { Yes } \\
p>.0000\end{array}$ \\
\hline
\end{tabular}

*Robust standards errors and absolute values of t statistics reported beneath regression coefficients in parenthesis. Sample size 480 
Table 3 : Estimates of Savings Model with Lagged Savings Endogenous

\begin{tabular}{|c|c|c|c|c|c|}
\hline \multirow{2}{*}{$\begin{array}{l}\text { Explanatory } \\
\text { Variables }\end{array}$} & \multirow[b]{2}{*}{$\begin{array}{l}\text { Endogenous LS } \\
\text { (no trend) } \\
(E-1)\end{array}$} & \multirow[b]{2}{*}{$\begin{array}{l}\text { Linear } \\
\text { Time Trend } \\
\text { (E-2) }\end{array}$} & \multirow[b]{2}{*}{$\begin{array}{l}\text { Quadratic } \\
\text { Time Trend } \\
\text { (E-3) }\end{array}$} & \multicolumn{2}{|c|}{ Country Specific Trends } \\
\hline & & & & $\begin{array}{l}\text { Linear } \\
(E-4)\end{array}$ & $\begin{array}{l}\text { Quadratic } \\
\text { (E-5) }\end{array}$ \\
\hline Lagged Savings & $\begin{array}{l}.894 \\
(10.9)\end{array}$ & $\begin{array}{l}.869 \\
(10.9)\end{array}$ & $\begin{array}{l}.870 \\
(10.2)\end{array}$ & $\begin{array}{l}.500 \\
(3.72)\end{array}$ & $\begin{array}{l}.477 \\
(3.33)\end{array}$ \\
\hline Growth & $\begin{array}{l}.0591 \\
(.33)\end{array}$ & $\begin{array}{l}.0706 \\
(.41)\end{array}$ & $\begin{array}{l}.0985 \\
(.56)\end{array}$ & $\begin{array}{l}.251 \\
(1.59)\end{array}$ & $\begin{array}{l}.139 \\
(1.24)\end{array}$ \\
\hline RPI & $\begin{array}{l}.0142 \\
(1.65)\end{array}$ & $\begin{array}{l}.0159 \\
(1.78)\end{array}$ & $\begin{array}{l}.0192 \\
(1.97)\end{array}$ & $\begin{array}{l}.0670 \\
(2.86)\end{array}$ & $\begin{array}{l}.0715 \\
(2.31)\end{array}$ \\
\hline Z 1 & $\begin{array}{l}.0866 \\
(1.21)\end{array}$ & $\begin{array}{l}.0814 \\
(1.38)\end{array}$ & $\begin{array}{l}.0911 \\
(1.32)\end{array}$ & $\begin{array}{l}.147 \\
(1.74)\end{array}$ & $\begin{array}{l}.131 \\
(.98)\end{array}$ \\
\hline $\mathrm{Z} 2$ & $\begin{array}{l}-.0054 \\
(1.10)\end{array}$ & $\begin{array}{l}-.0052 \\
(1.28)\end{array}$ & $\begin{array}{l}-.0055 \\
(1.19)\end{array}$ & $\begin{array}{l}-.0129 \\
(1.86)\end{array}$ & $\begin{array}{l}-.0018 \\
(.18)\end{array}$ \\
\hline $\begin{array}{l}\text { Year (linear) } \\
\left(\times 10^{-2}\right)\end{array}$ & & $\begin{array}{l}.0244 \\
(.97)\end{array}$ & $\begin{array}{l}.139 \\
(1.59)\end{array}$ & -- & -- \\
\hline $\begin{array}{l}\text { Year Squared } \\
\left(X 10^{-4}\right)\end{array}$ & & & $\begin{array}{l}-.258 \\
(1.49)\end{array}$ & & -- \\
\hline Pseudo $\mathrm{R}^{2}$ & .927 & .929 & .929 & .934 & .944 \\
\hline $\begin{array}{l}\text { Hausman Test for the } \\
\text { Rejection of Exogeneity of } \\
\text { Lagged Savings } \\
p>|t|\end{array}$ & $\begin{array}{l}2.84 \\
(.005)\end{array}$ & $\begin{array}{l}2.46 \\
(.014)\end{array}$ & $\begin{array}{l}2.70 \\
(.007)\end{array}$ & $\begin{array}{l}.84 \\
(.40)\end{array}$ & $\begin{array}{l}1.03 \\
(.31)\end{array}$ \\
\hline $\begin{array}{l}\text { Joint Significance of } F \\
\text { Test Age Composition ( } p> \\
F)\end{array}$ & $\begin{array}{l}(2,459) \\
=1.34 \\
(.26)\end{array}$ & $\begin{array}{l}(2,458) \\
=1.29 \\
(.28)\end{array}$ & $\begin{array}{l}(2,457) \\
=1.48 \\
(.23)\end{array}$ & $\begin{array}{l}(2,443) \\
=1.88 \\
(.15)\end{array}$ & $\begin{array}{l}(2,427) \\
=2.41 \\
(.091)\end{array}$ \\
\hline $\begin{array}{l}\text { Country Specific Trend: } \\
\text { Year (linear) } \\
\text { Year Squared }\end{array}$ & & & & $\begin{array}{l}\text { Yes } \\
p>.33 \\
\text { No }\end{array}$ & $\begin{array}{l}\text { Yes } \\
\text { Yes } \\
p>.66\end{array}$ \\
\hline
\end{tabular}


Table 4: Estimates of Savings Model with Endogenous Lagged Savings Using First Differences*

\begin{tabular}{|c|c|c|c|c|c|}
\hline \multirow{2}{*}{$\begin{array}{l}\text { Explanatory } \\
\text { Variables }\end{array}$} & \multirow[b]{2}{*}{$\begin{array}{l}\text { Endogenous } \\
\text { Lagged } \\
\text { Saving } \\
\text { (no trend) } \\
\text { (FD-1) }\end{array}$} & \multirow[b]{2}{*}{$\begin{array}{l}\text { Linear } \\
\text { Time } \\
\text { (FD-2) }\end{array}$} & \multirow[b]{2}{*}{$\begin{array}{l}\text { Quadratic } \\
\text { Time } \\
\text { (FD-3) }\end{array}$} & \multicolumn{2}{|c|}{ Country Specific Trends } \\
\hline & & & & $\begin{array}{l}\text { Linear } \\
\text { (FD-4) }\end{array}$ & $\begin{array}{l}\text { Quadratic } \\
\text { (FD-5) }\end{array}$ \\
\hline Lagged Savings & $\begin{array}{l}-.0201 \\
(.01)\end{array}$ & $\begin{array}{l}-.250 \\
(.27)\end{array}$ & $\begin{array}{l}-.503 \\
(.58)\end{array}$ & $\begin{array}{l}-.766 \\
(.77)\end{array}$ & $\begin{array}{l}.448 \\
(.51)\end{array}$ \\
\hline Growth & $\begin{array}{l}.0887 \\
(.61)\end{array}$ & $\begin{array}{l}.038 \\
(.30)\end{array}$ & $\begin{array}{l}-.0154 \\
(.14)\end{array}$ & $\begin{array}{l}-.0462 \\
(.42)\end{array}$ & $\begin{array}{l}.0953 \\
(1.04)\end{array}$ \\
\hline RPI & $\begin{array}{l}.336 \\
(1.15)\end{array}$ & $\begin{array}{l}.220 \\
(.65)\end{array}$ & $\begin{array}{l}.0549 \\
(.27)\end{array}$ & $\begin{array}{l}-.0672 \\
(.92)\end{array}$ & $\begin{array}{l}-.0044 \\
(.11)\end{array}$ \\
\hline Z 1 & $\begin{array}{l}.419 \\
(.57)\end{array}$ & $\begin{array}{l}.538 \\
(1.11)\end{array}$ & $\begin{array}{l}.691 \\
(1.56)\end{array}$ & $\begin{array}{l}.756 \\
(1.40)\end{array}$ & $\begin{array}{l}-.0029 \\
(.00)\end{array}$ \\
\hline Z 2 & $\begin{array}{l}-.0206 \\
(1.14)\end{array}$ & $\begin{array}{l}-.0311 \\
(.93)\end{array}$ & $\begin{array}{l}-.0434 \\
(1.36)\end{array}$ & $\begin{array}{l}-.0573 \\
(1.42)\end{array}$ & $\begin{array}{l}.0010 \\
(.02)\end{array}$ \\
\hline $\begin{array}{l}\text { Constant or } \\
\text { Year (linear) }\end{array}$ & & $\begin{array}{l}.159 \\
(.34)\end{array}$ & $\begin{array}{l}.563 \\
(1.22)\end{array}$ & -- & -- \\
\hline $\begin{array}{l}\text { Year Squared } \\
\left(X 10^{-4}\right)\end{array}$ & & & $\begin{array}{l}-.535 \\
(.44)\end{array}$ & & -- \\
\hline F stat $(p>F)$ & $\begin{array}{l}1.80 \\
(.11)\end{array}$ & $\begin{array}{l}.71 \\
(.61)\end{array}$ & $\begin{array}{l}1.02 \\
(.41)\end{array}$ & $\begin{array}{l}.66 \\
(.87)\end{array}$ & $\begin{array}{l}.60 \\
(.97)\end{array}$ \\
\hline $\begin{array}{l}\text { Joint Significance of } F \\
\text { Test } \\
\text { Age Composition }(p>F)\end{array}$ & $\begin{array}{l}(2,464) \\
=.43 \\
(.65)\end{array}$ & $\begin{array}{l}(2,463) \\
=.74 \\
(.48)\end{array}$ & $\begin{array}{l}(2,462) \\
=1.49 \\
(.23)\end{array}$ & $\begin{array}{l}(2,448) \\
=1.01 \\
(.36)\end{array}$ & $\begin{array}{l}(2,432) \\
=.00 \\
(.99)\end{array}$ \\
\hline $\begin{array}{l}\text { Country Specific Trend: } \\
\text { Year (linear) } \\
\text { Year Squared }\end{array}$ & & & & $\begin{array}{l}\text { Yes } \\
(.99)\end{array}$ & $\begin{array}{l}\text { Yes } \\
\text { Yes } \\
(.21)\end{array}$ \\
\hline
\end{tabular}

*Absolute value of robust $t$ statistic reported in parenthesis beneath coefficients. Sample size is 469 because differencing of data eliminates the first observation for each country. 
Table 5: Estimates of Savings Model with Lagged Savings including Young and Old Dependent Age Categories*

\begin{tabular}{|c|c|c|c|c|c|c|}
\hline \multirow{2}{*}{$\begin{array}{l}\text { Explanatory } \\
\text { Variables }\end{array}$} & \multirow[b]{2}{*}{$\begin{array}{l}\text { Exogenous LS } \\
\text { (no trend) } \\
\qquad(\mathrm{X}-1)\end{array}$} & \multirow[b]{2}{*}{$\begin{array}{l}\text { Endogenous LS } \\
\text { (no trends) } \\
\text { (E-1) }\end{array}$} & \multirow[b]{2}{*}{$\begin{array}{l}\text { Linear } \\
\text { Time } \\
(E-2)\end{array}$} & \multirow[b]{2}{*}{$\begin{array}{l}\text { Quadratic } \\
\text { Time } \\
\text { (E-3) }\end{array}$} & \multicolumn{2}{|c|}{ Country Specific } \\
\hline & & & & & $\begin{array}{l}\text { Linear } \\
\text { (E-4) }\end{array}$ & $\begin{array}{l}\text { Quadratic } \\
\text { (E-5) }\end{array}$ \\
\hline Lagged Savings & $\begin{array}{l}.839 \\
(18.2)\end{array}$ & $\begin{array}{l}.946 \\
(15.8)\end{array}$ & $\begin{array}{l}.899 \\
(12.5)\end{array}$ & $\begin{array}{l}.891 \\
(11.5)\end{array}$ & $\begin{array}{l}.568 \\
(4.25)\end{array}$ & $\begin{array}{l}.453 \\
(2.96)\end{array}$ \\
\hline Growth & $\begin{array}{l}-.239 \\
(1.44)\end{array}$ & $\begin{array}{l}.135 \\
(.84)\end{array}$ & $\begin{array}{l}.104 \\
(.73)\end{array}$ & $\begin{array}{l}.131 \\
(.93)\end{array}$ & $\begin{array}{l}.304 \\
(.50)\end{array}$ & $\begin{array}{l}.180 \\
(1.80)\end{array}$ \\
\hline RPI & $\begin{array}{l}.00810 \\
(.86)\end{array}$ & $\begin{array}{l}.0124 \\
(1.48)\end{array}$ & $\begin{array}{l}.0144 \\
(1.70)\end{array}$ & $\begin{array}{l}.0177 \\
(1.91)\end{array}$ & $\begin{array}{l}.0674 \\
(2.70)\end{array}$ & $\begin{array}{l}.0793 \\
(2.43)\end{array}$ \\
\hline Youth (0-19) Proportion & $\begin{array}{l}-.243 \\
(2.97)\end{array}$ & $\begin{array}{l}-.0913 \\
(.93)\end{array}$ & $\begin{array}{l}-.101 \\
(1.13)\end{array}$ & $\begin{array}{l}-.164 \\
(1.35)\end{array}$ & $\begin{array}{l}-.0893 \\
(.74)\end{array}$ & $\begin{array}{l}-.103 \\
(.44)\end{array}$ \\
\hline $\begin{array}{l}\text { Elderly ( } 60 \text { or more) } \\
\text { Proportion }\end{array}$ & $\begin{array}{l}-.442 \\
(2.05)\end{array}$ & $\begin{array}{l}-.0854 \\
(.32)\end{array}$ & $\begin{array}{l}-.184 \\
(.72)\end{array}$ & $\begin{array}{l}-.206 \\
(.76)\end{array}$ & $\begin{array}{l}-.796 \\
(1.22)\end{array}$ & $\begin{array}{l}2.99 \\
(2.13)\end{array}$ \\
\hline $\begin{array}{l}\text { Year (linear) } \\
\left(\times 10^{-2}\right)\end{array}$ & & & $\begin{array}{l}.034 \\
(1.24)\end{array}$ & $\begin{array}{l}.147 \\
(1.50)\end{array}$ & & \\
\hline $\begin{array}{l}\text { Year Squared } \\
\left(\times 10^{-4}\right)\end{array}$ & & & & $\begin{array}{l}-.25 \\
(1.36)\end{array}$ & & \\
\hline Pseudo $\mathbf{R}^{2}$ & .903 & .923 & .927 & .927 & .928 & .942 \\
\hline $\begin{array}{l}\text { Joint Significance of F Test } \\
\text { Age Composition } \\
(p>F)\end{array}$ & $\begin{array}{l}(2,459) \\
=4.43 \\
(.012) \\
\end{array}$ & $\begin{array}{l}(2,459) \\
=.73 \\
(.48)\end{array}$ & $\begin{array}{l}(2,458) \\
=.68 \\
(.51)\end{array}$ & $\begin{array}{l}(2,457) \\
=1.08 \\
(.34)\end{array}$ & $\begin{array}{l}(2,443) \\
=.78 \\
(.46)\end{array}$ & $\begin{array}{l}(2,380) \\
=2.66 \\
(.071)\end{array}$ \\
\hline $\begin{array}{l}\text { Country Specific Trend: } \\
\text { Year (linear) } \\
\text { Year Squared }\end{array}$ & & & & & $\begin{array}{l}\text { Yes } \\
p>.49\end{array}$ & $\begin{array}{l}\text { Yes } \\
\text { Yes } \\
p>.74\end{array}$ \\
\hline
\end{tabular}

*Robust standards errors and absolute values of $t$ statistics reported beneath regression coefficients in parenthesis. Sample size $\mathbf{4 8 0}$ 


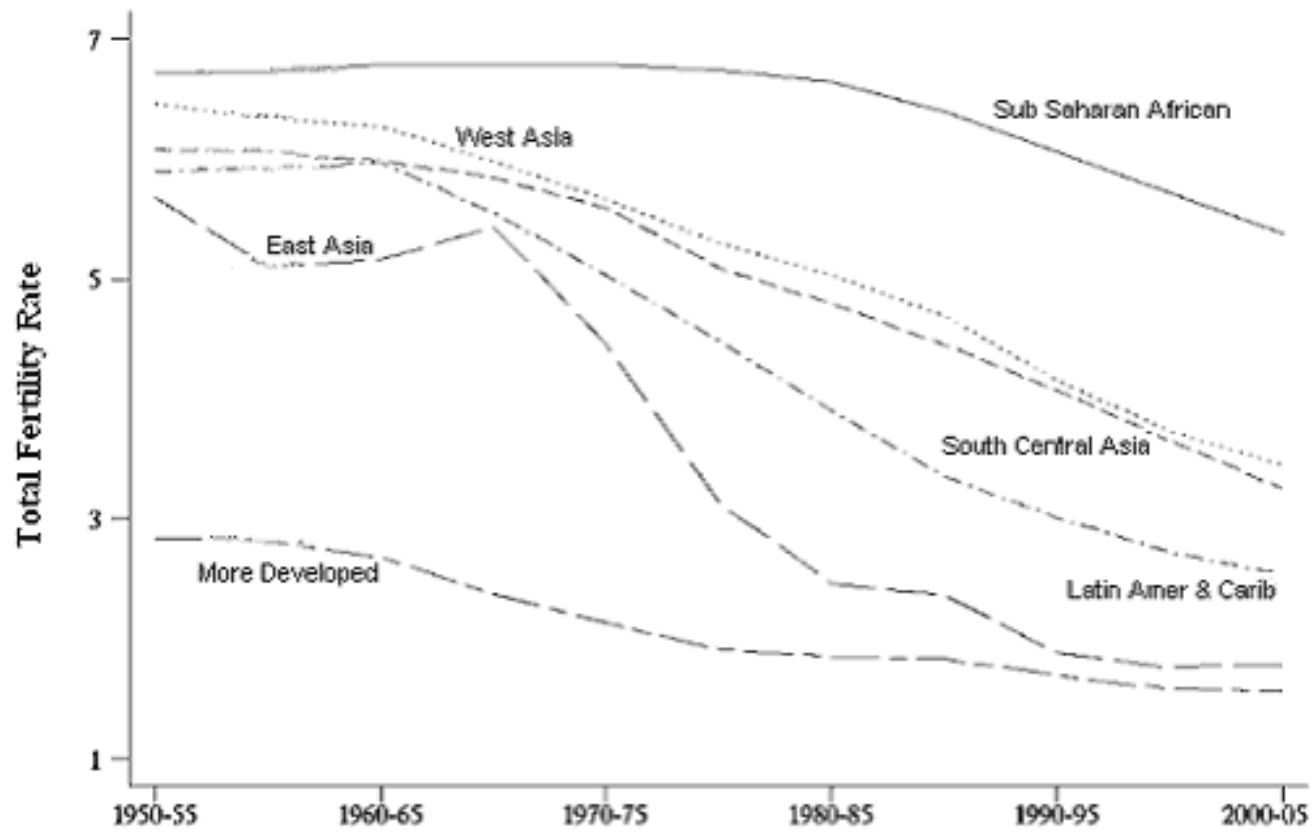

Fig 1. Total Fertility Rates by Region (United Nations 2003) 
Figures 2. Youth and Elderly Proportions of Population and Share Of Savings in GDP : Selected Asian Countries 1950 - 1990

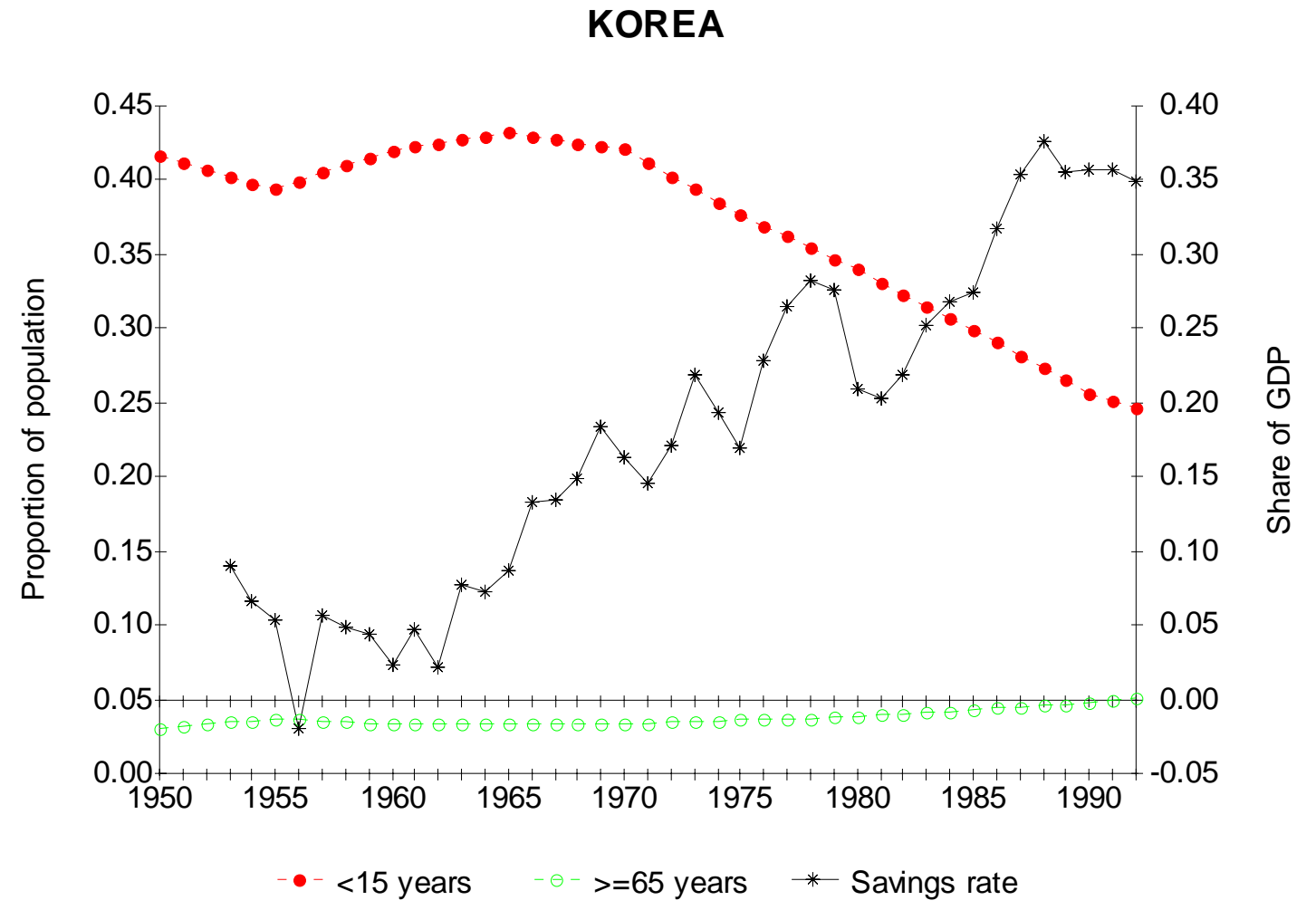




\section{TAIWAN}

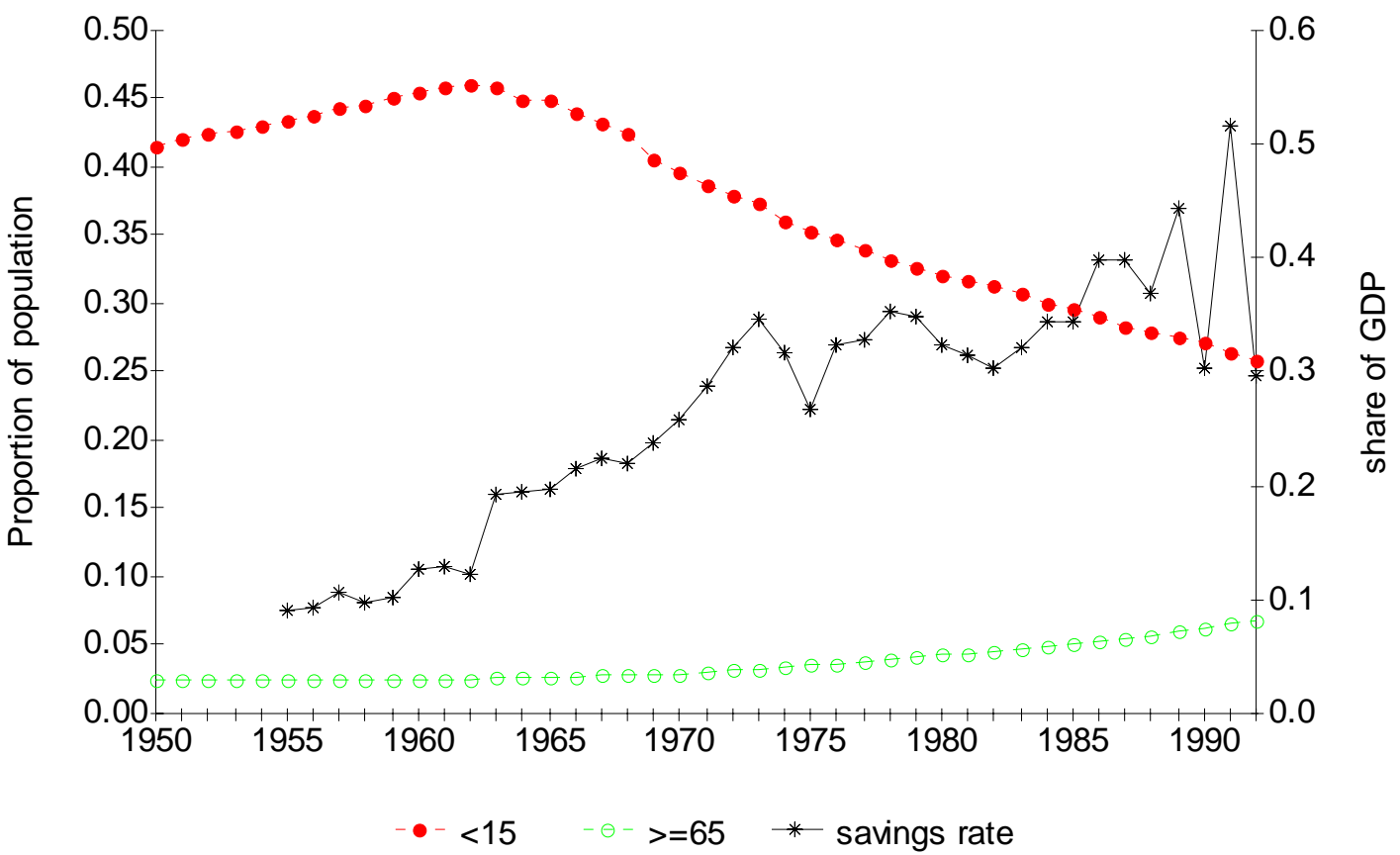

INDIA

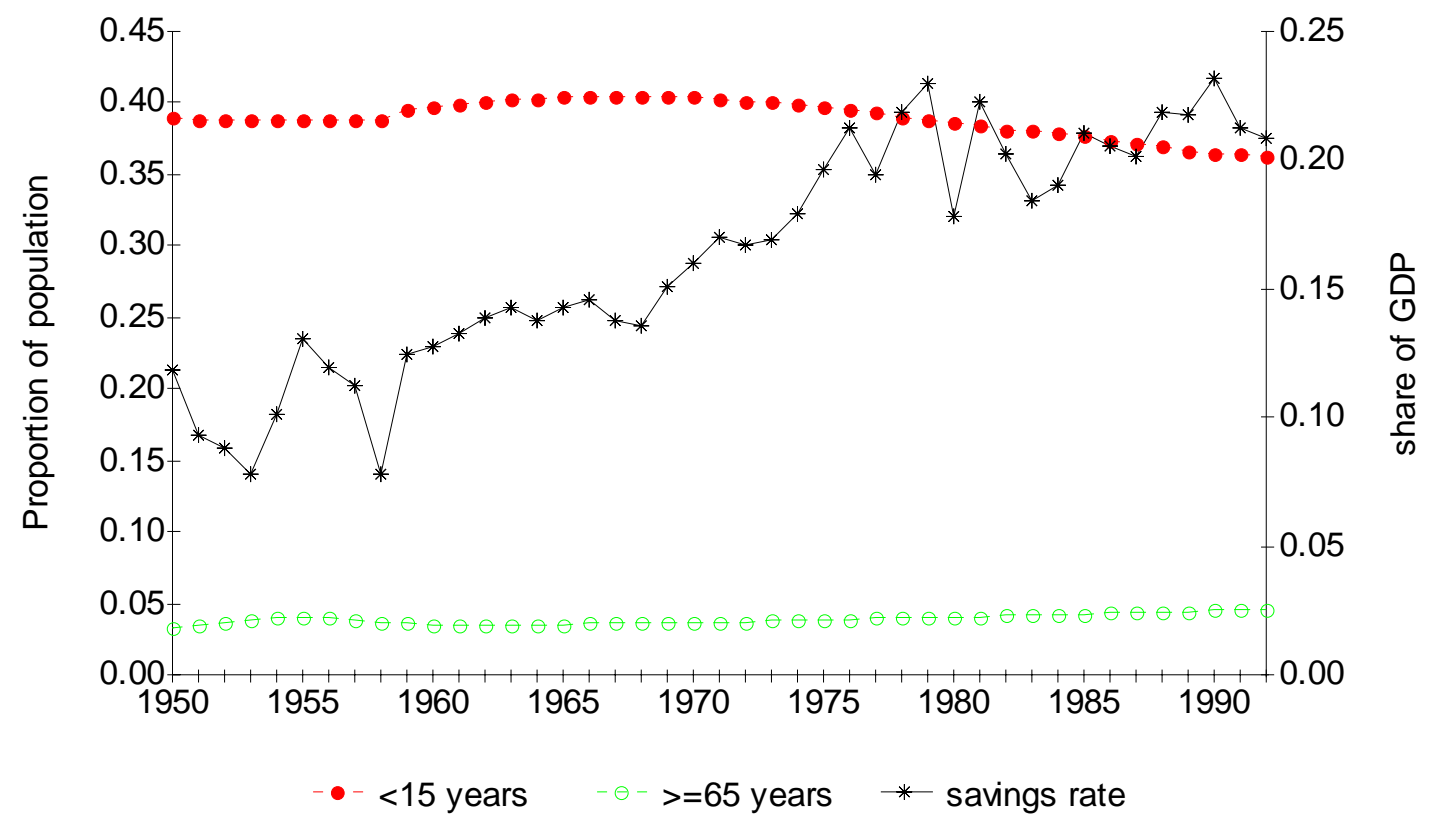


MALAYSIA

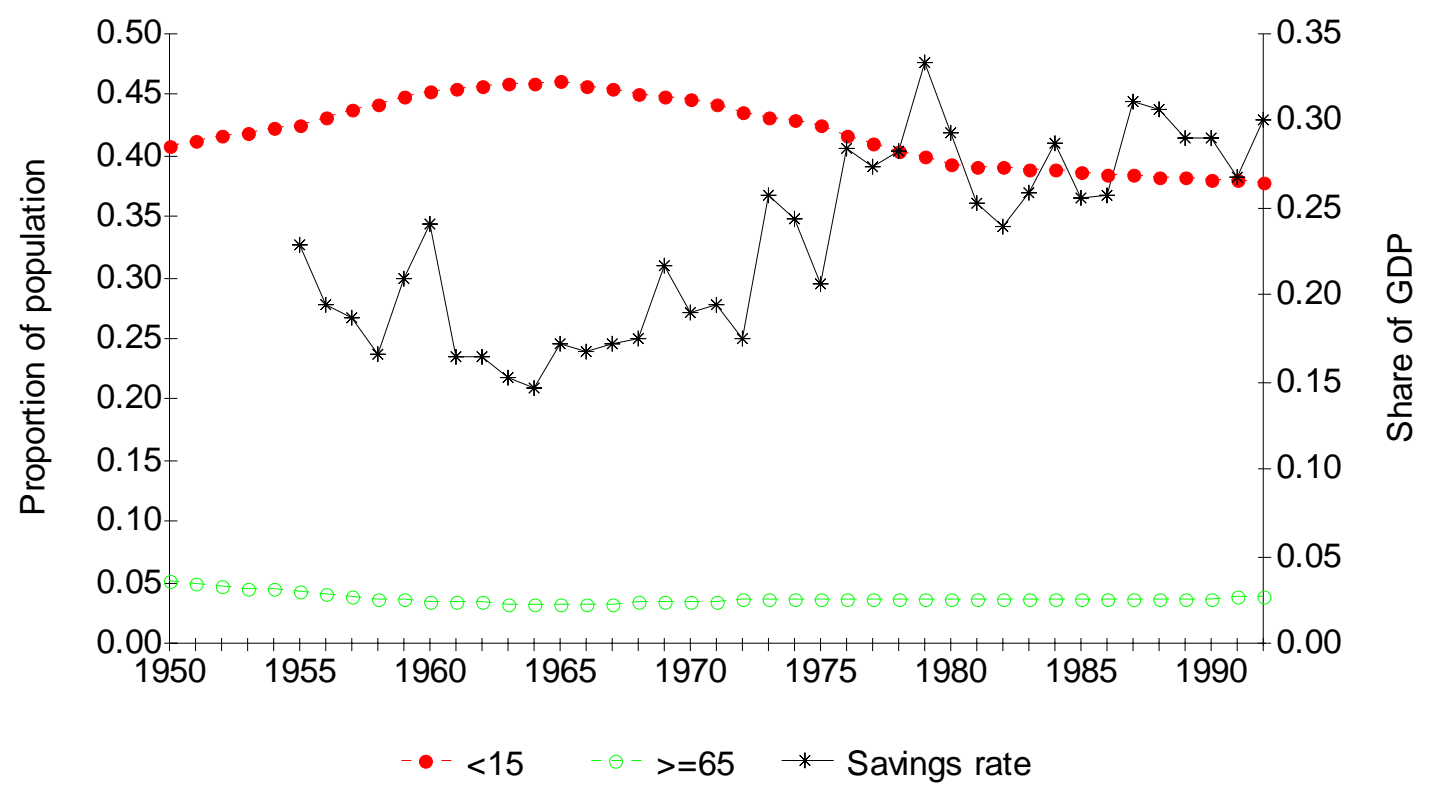

THAILAND

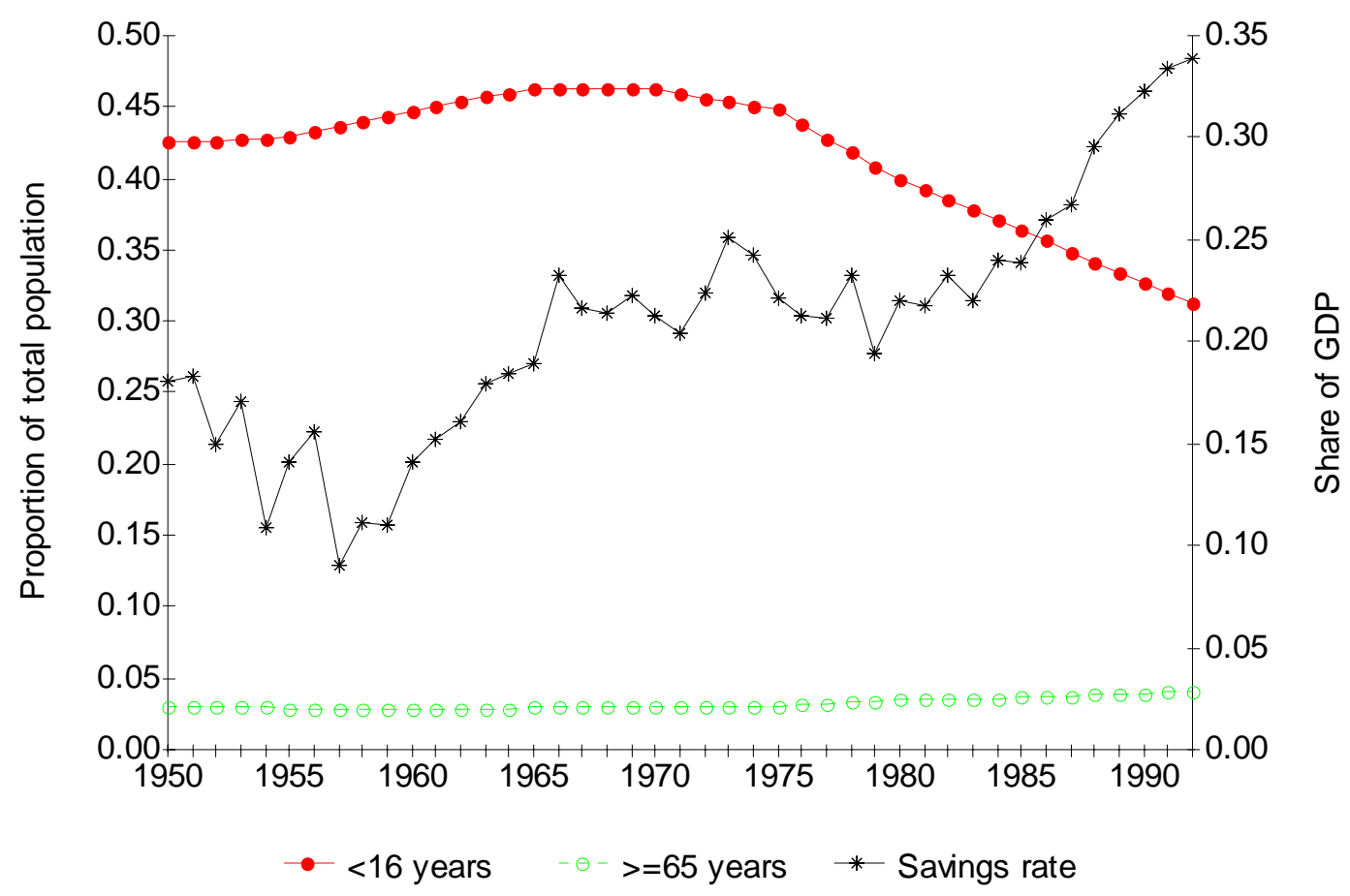




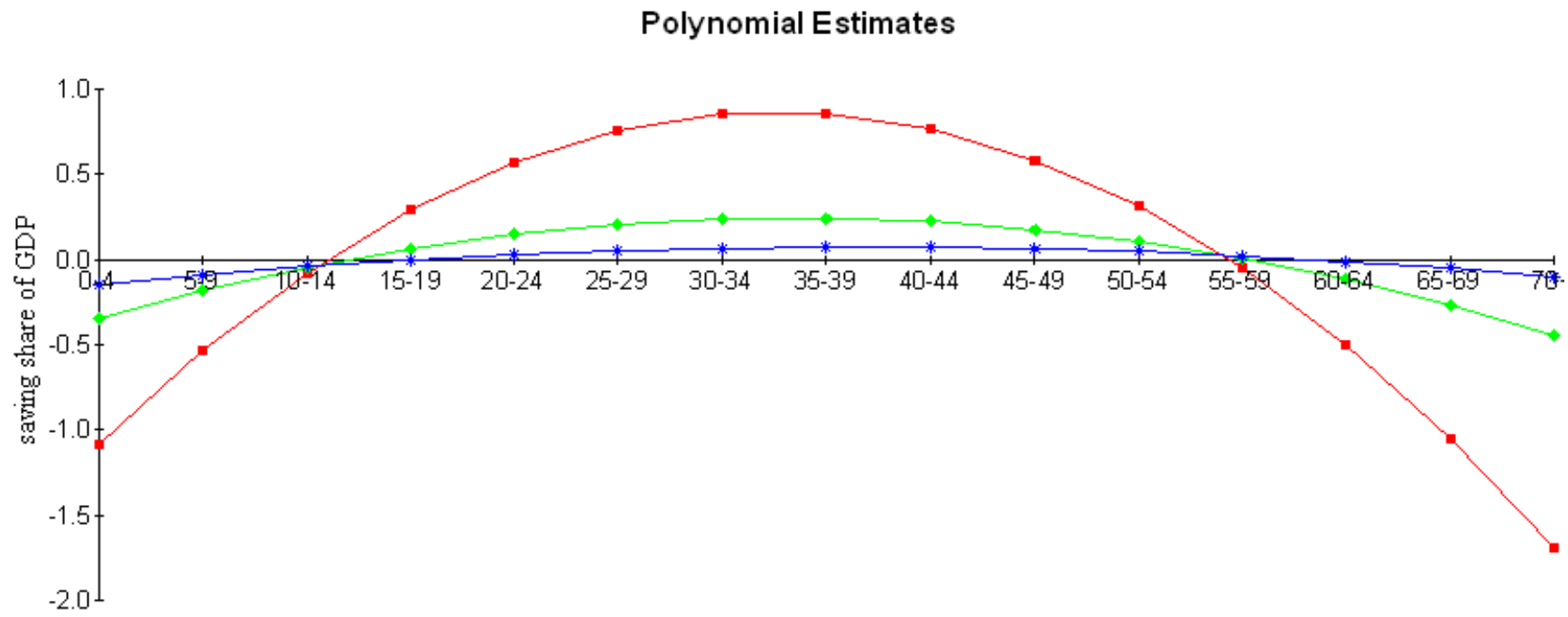

Age Group

$\rightarrow$ H\&W table $7 \rightarrow-$ Exogenous LDV * Endogenous LDV

\section{Fig. 3 Alternative Estimates of Quadratic Polynomial of Age Effects on Savings Proportion}

Sources: Higgins and Williamson, 1996, Table 7 (Table 2, Col. 1)

Exogenous Lagged Dependent Variable (Table 2, Col. 2), with no time trends

Endogenous Lagged Dependent Variable (Table 3, Col. 1), with no time trends 